\title{
Growth-independent cross-feeding modifies boundaries for coexistence in a bacterial mutualism
}

Running title: Growth-independent metabolism in a mutualism

Alexandra L. McCully*, Breah LaSarre*, and James B. McKinlay*

*Both authors contributed equally to this work

${ }^{\#}$ Corresponding author. 1001 E $3^{\text {rd }}$ Street, Jordan Hall, Bloomington, IN 47405

Phone: 812-855-0359

Fax: 812-855-6705

Email: jmckinla@indiana.edu

\section{Significance statement.}

Microbial mutualisms, such as those enforced by cross-feeding of metabolites, are widespread yet invariably face periods of nutrient limitation. Here we use experimental and theoretical approaches involving a synthetic community of two bacterial species to identify growthindependent maintenance metabolism as an important mechanism by which mutualistic crossfeeding can establish and persist in the face of nutrient limitation. 


\section{Summary}

Nutrient cross-feeding can stabilize microbial mutualisms, including those important for carbon cycling in nutrient-limited anaerobic environments. It remains poorly understood how nutrient limitation within natural environments impacts mutualist growth, cross-feeding levels, and ultimately mutualism dynamics. We examined the effects of nutrient limitation within a mutualism using theoretical and experimental approaches with a synthetic anaerobic coculture pairing fermentative Escherichia coli and phototrophic Rhodopseudomonas palustris. In this coculture, E. coli and $R$. palustris resemble an anaerobic food web by cross-feeding essential carbon (organic acids) and nitrogen (ammonium), respectively. Organic acid cross-feeding stemming from $E$. coli fermentation can continue in a growth-independent manner during nutrient limitation, while ammonium cross-feeding by $R$. palustris is growth-dependent. When ammonium cross-feeding was limited, coculture trends changed yet coexistence persisted under both homogenous and heterogenous conditions. Theoretical modeling indicated that growthindependent fermentation was crucial to sustain cooperative growth under conditions of low nutrient exchange. In contrast to stabilization at low cell density, growth-independent fermentation inhibited mutualistic growth when the $E$. coli cell density was adequately high relative to that of $R$. palustris. Thus, growth-independent fermentation can conditionally stabilize or destabilize a mutualism, indicating the potential importance of growth-independent metabolism for nutrient-limited mutualistic communities. 


\section{Introduction}

Mutualistic cross-feeding interactions between microbes crucially impact diverse processes ranging from human health (Flint et al., 2007; Ramsey and Whiteley, 2009; Hammer et al., 2014) to biogeochemical cycles (McInerney et al., 2010; Morris et al., 2013; Durham et al., 2015). Within most environments, microbial communities experience prolonged periods of nutrient limitation (Lever et al., 2015). In general, bacteria tolerate nutrient limitation by modulating their growth and metabolism (Lee et al., 1976; Wanner and Egli, 1990; Russell and Cook, 1995; Ferenci, 2001; Rittershaus et al., 2013). Sub-optimally growing and even nongrowing cells continue to generate maintenance energy, that is energy required for any process that is not directly used for synthesizing and polymerizing biosynthetic precursors, and thereby survive by retaining partial metabolic activity (Wanner and Egli, 1990; Russell and Cook, 1995; Hoehler and Jørgensen, 2013; Rittershaus et al., 2013). We hereon refer to this growthindependent metabolic activity for cell maintenance as maintenance metabolism. While maintenance metabolism occurs during growth, it can make up the majority of metabolic activity in slow-growing and especially non-growing cells. As a consequence of maintenance metabolism being independent of growth, the overall metabolic activity of a cell does not decline proportionately to growth rate during nutrient limitation.

For fermentative microbes, the transformation of energy into ATP and a proton motive force is intimately associated with the excretion of fermentation products. During nutrient limitation, the maintenance metabolism of fermentative microbes is associated with product excretion, albeit at a lower rate than during growth. For example, in the absence of electron acceptors, and starved for essential elements (i.e., nitrogen or sulfur), Escherichia coli generates energy by fermenting glucose in a growth-independent manner (Wanner and Egli, 1990; LaSarre 
et al., 2017). Fermentative microbes serve pivotal roles within natural anaerobic food webs, wherein their excreted products serve as nutrients for other microbes. It is possible that fermentation products associated with maintenance metabolism could serve to cross-feed other microbes and thereby influence the initiation and/or endurance of microbial mutualisms under growth-limiting conditions. Nonetheless, most microbial cross-feeding studies view nutrient release as being tightly coupled to growth. While mutualism flux balance models tend to include growth-independent maintenance parameters (Harcombe et al., 2014; Chubiz et al., 2015), most other mutualism models do not, and few studies have examined the impact of growthindependent cross-feeding on mutualism dynamics (Megee III et al., 1972; Shou et al., 2007; Stolyar et al., 2007). Studying mutualistic cross-feeding in natural environments can be challenging due to environmental and genetic stochasticity. Synthetic microbial communities, or cocultures, offer an alternative approach that mimics key aspects of natural communities while providing a greater degree of experimental control (Momeni et al., 2011; Ponomarova and Patil, 2015; Lindemann et al., 2016; Widder et al., 2016). We previously developed a bacterial coculture to facilitate the study of mutualistic cross-feeding in anaerobic environments (LaSarre et al., 2017) (Fig. 1). Our coculture resembles other fermenter-photoheterotroph cocultures, which have primarily been studied for converting plant-derived sugars into $\mathrm{H}_{2}$ biofuel (Odom and Wall, 1983; Fang et al., 2006; Ding et al., 2009; Sun et al., 2010). However, unlike previous systems, our coculture enforces stable coexistence through bi-directional cross-feeding of essential nutrients. Specifically, E. coli ferments sugars to excreted organic acids, providing essential carbon and electrons for a genetically engineered Rhodopseudomonas palustris strain (Nx). R. palustris $\mathrm{Nx}$ has a NifA* mutation (McKinlay and Harwood, 2010) that results in $\mathrm{NH}_{4}{ }^{+}$ excretion during $\mathrm{N}_{2}$ fixation, providing essential nitrogen for $E$. coli (LaSarre et al., 2017). We 
previously used our coculture to examine the effects of increased $\mathrm{NH}_{4}{ }^{+}$cross-feeding on coculture dynamics (LaSarre et al., 2017). In that study, theoretical modeling suggested that coexistence would persist even at very low $\mathrm{NH}_{4}{ }^{+}$excretion levels (LaSarre et al., 2017). This prediction prompted us to ask herein, how does this mutualism contend with limitation of crossfed nutrients?

Using theoretical and experimental approaches, we show that fermentative maintenance metabolism is crucial for maintaining cooperative growth during limitation of cross-fed $\mathrm{NH}_{4}{ }^{+}$. Conversely, fermentative maintenance metabolism is detrimental to the mutualism under circumstances where the E. coli cell density far exceeds that of R. palustris, as the otherwise low maintenance metabolism rate is magnified and leads to an inhibitory acidification of the environment. Thus, growth-independent cross-feeding conditionally influences this mutualism in positive and negative manners and thereby sets both the lower and upper thresholds for cooperation.

\section{Results}

Coexistence is maintained at reduced $\mathrm{NH}_{4}{ }^{+}$cross-feeding levels. Previously, we found that stable coexistence and reproducible trends in our mutualistic coculture were dependent on the transfer of $\mathrm{NH}_{4}{ }^{+}$from R. palustris $\mathrm{Nx}$ to $E$. coli (LaSarre et al., 2017). Adding $\mathrm{NH}_{4}{ }^{+}$to the medium broke the dependency of $E$. coli on $R$. palustris and resulted in E. coli domination due to its higher intrinsic growth rate relative to that of $R$. palustris. Thus, the $\mathrm{NH}_{4}{ }^{+}$cross-feeding level controls the $E$. coli growth rate within the mutualism. We were intrigued that theoretical modeling predicted that mutualism coexistence would be maintained even at very low $\mathrm{NH}_{4}{ }^{+}$ 
cross-feeding levels, as such levels should severely limit or event halt $E$. coli growth (Supporting Information Fig. S1A) (LaSarre et al., 2017).

To test this prediction, we sought to experimentally manipulate $R$. palustris $\mathrm{NH}_{4}^{+}$ excretion. In our previous study, cocultures were grown under a $100 \% \mathrm{~N}_{2}$ headspace with shaking to promote gas exchange and homogenous conditions (LaSarre et al., 2017). Under these conditions, the NifA* mutation presumably results in a rate of $\mathrm{N}_{2}$ fixation that exceeds the rate of biosynthesis, leading to excretion of excess $\mathrm{NH}_{4}{ }^{+}$. We therefore reasoned that limiting the $\mathrm{N}_{2}$ supply in shaken cocultures could lower the rate of $\mathrm{NH}_{4}{ }^{+}$production by nitrogenase, and consequently $R$. palustris $\mathrm{Nx}$ would retain a larger portion of the $\mathrm{NH}_{4}{ }^{+}$for biosynthesis and excrete less. To limit the $\mathrm{N}_{2}$ concentration, we injected $\mathrm{N}_{2}$ into sealed coculture tubes with an argon-filled headspace to reach a final concentration of $18 \% \mathrm{~N}_{2}$, a concentration we estimated would be close to limiting $R$. palustris growth in our coculture conditions, based on the elemental composition of $R$. palustris (McKinlay and Harwood, 2010). In agreement with our expectation, supernatants from shaking $R$. palustris monocultures with $18 \% \mathrm{~N}_{2}$ contained half as much $\mathrm{NH}_{4}{ }^{+}$compared to $100 \% \mathrm{~N}_{2}$ monocultures (Fig. 2). We concluded that $\mathrm{N}_{2}$ limitation was a suitable approach to manipulate $\mathrm{NH}_{4}{ }^{+}$excretion levels.

To examine the degree of $\mathrm{N}_{2}$ limitation that would support coexistence, we grew cocultures with a range of $\mathrm{N}_{2}$ concentrations and monitored $\mathrm{H}_{2}$ yields and growth rates. We used $\mathrm{H}_{2}$ yield as a proxy for $\mathrm{N}_{2}$ limitation because nitrogenase produces more $\mathrm{H}_{2}$ and less $\mathrm{NH}_{4}{ }^{+}$as $\mathrm{N}_{2}$ becomes limiting (Hoffman et al., 2013). When nitrogenase is saturated with $\mathrm{N}_{2}$, one mole of $\mathrm{H}_{2}$ is obligately produced for every mole of $\mathrm{N}_{2}$ converted into $2 \mathrm{NH}_{4}^{+}$(Eq 1). In the absence of $\mathrm{N}_{2}$, nitrogenase continues to oxidize electron carriers and acts as an ATP-powered hydrogenase, 
producing $\mathrm{H}_{2}$ as the sole product (Eq 2). Under sub-saturating $\mathrm{N}_{2}$ conditions, the stoichiometric amounts of $\mathrm{NH}_{4}{ }^{+}$and $\mathrm{H}_{2}$ produced would be somewhere between Eqs. 1 and 2.

$$
\begin{aligned}
& \text { Eq 1. } \mathrm{N}_{2}+10 \mathrm{H}^{+}+8 \mathrm{e}^{-}+16 \mathrm{ATP} \rightarrow 2 \mathrm{NH}_{4}{ }^{+}+\mathrm{H}_{2}+16 \text { ADP } \\
& \text { Eq 2. } \quad 8 \mathrm{H}^{+}+8 \mathrm{e}^{-}+16 \mathrm{ATP} \rightarrow
\end{aligned}
$$

Thus, progressively decreased $\mathrm{N}_{2}$ availability should result in less $\mathrm{NH}_{4}{ }^{+}$excretion and more $\mathrm{H}_{2}$ production. Unlike $\mathrm{NH}_{4}{ }^{+}, \mathrm{H}_{2}$ accumulates in coculture, making it a convenient compound to assess whether $R$. palustris cells in coculture are experiencing sub-saturating $\mathrm{N}_{2}$ conditions. $\mathrm{N}_{2}$ limited cocultures were incubated horizontally with shaking to promote a homogeneous environment. As expected, the coculture $\mathrm{H}_{2}$ yield increased as $\mathrm{N}_{2}$ concentration decreased, but the yield plateaued at $\mathrm{N}_{2}$ concentrations below $15 \%$ (Fig. $3 \mathrm{~A}$ ). Below $15 \% \mathrm{~N}_{2}$, R. palustris might redirect electrons away from $\mathrm{H}_{2}$ production towards other products like polyhydroxybutyrate, as has been observed as part of a nitrogen-starvation response in R. palustris (McKinlay et al., 2014). $\mathrm{N}_{2}$ limitation was also evident from the coculture growth rate, which decreased as the $\mathrm{N}_{2}$ concentration decreased (Fig. 3B; Supporting Information Fig. S2A). Notably, cocultures still grew at the lowest concentration of $\mathrm{N}_{2}$ tested ( $6 \%$ headspace $\mathrm{N}_{2}$; Fig. $\left.3 \mathrm{~B}\right)$, indicating that sufficient $\mathrm{NH}_{4}{ }^{+}$was cross-fed to permit mutualistic growth.

Moving forward, we focused on $18 \% \mathrm{~N}_{2}$ to characterize how lower $\mathrm{NH}_{4}{ }^{+}$cross-feeding affected coculture dynamics. We chose $18 \% \mathrm{~N}_{2}$ as a concentration where nitrogen-limitation impacted coculture trends but without causing the observed $\mathrm{H}_{2}$ yield plateau (Fig. 3). Previous model simulations predicted that decreasing $\mathrm{NH}_{4}{ }^{+}$cross-feeding would result in a decrease in the E. coli population within the coculture (Supporting Information Fig. S1A). In agreement with this, we observed that $E$. coli made up $5 \%$ of the population in the cocultures with $18 \% \mathrm{~N}_{2}$, which was significantly lower than the $9 \%$ E. coli frequency observed in cocultures with $100 \%$ 
$\mathrm{N}_{2}$ (Fig. 4A) (LaSarre et al., 2017). To assess coculture reproducibility, we performed serial transfers of cocultures with $18 \% \mathrm{~N}_{2}$. Growth yield, $\mathrm{H}_{2}$ yield, and growth rates were all reproducible across serial transfers (Fig. 4), indicating that coexistence was stable despite the lower level of $\mathrm{NH}_{4}^{+}$cross-feeding.

\section{Coexistence is maintained in heterogeneous environments that decrease $\mathrm{NH}_{4}{ }^{+}$cross-}

feeding. Spatial structuring can impact microbial mutualistic interactions, and is even required for coexistence in some cases (Kim et al., 2008; Harcombe, 2010; Summers et al., 2010; Hom and Murray, 2014). In other cases, well-mixed environments sufficiently promote cooperative relationships (Hillesland and Stahl, 2010; Mee et al., 2014; Pande et al., 2014). We hypothesized that the homogeneous environment in our shaking cocultures might dampen the impact of low $\mathrm{NH}_{4}{ }^{+}$cross-feeding levels. Thus, we examined whether a heterogeneous environment would affect coexistence within $\mathrm{N}_{2}$-limited cocultures.

One way to induce a heterogeneous environment is by incubating in static conditions, wherein cocultures are not agitated. Static incubation results in settling of cells to the bottom of the culture tube in both cocultures and R. palustris monocultures, which we expected would result in a gradient of $\mathrm{N}_{2}$ availability (Supporting Information Fig. S3). As $\mathrm{N}_{2}$ diffuses into the medium, $R$. palustris cells closer to surface would be first to encounter and utilize the $\mathrm{N}_{2}$, which would diminish the $\mathrm{N}_{2}$ available to $R$. palustris cells towards the bottom of the tube. The $\mathrm{N}_{2}-$ limited cells at the bottom of the tube would therefore produce less $\mathrm{NH}_{4}{ }^{+}$and more $\mathrm{H}_{2}$, leading to less $\mathrm{NH}_{4}{ }^{+}$excretion by the R. palustris population overall (Supporting Information Fig. S3). Confirming this hypothesis, static R. palustris Nx monocultures with $100 \% \mathrm{~N}_{2}$ grew to a similar density as when shaken, but showed less $\mathrm{NH}_{4}^{+}$excretion, similar to what was observed in 
monocultures shaken with $18 \% \mathrm{~N}_{2}$ (Fig. 2). This trend was exacerbated in static $R$. palustris $\mathrm{Nx}$ monocultures with only $18 \% \mathrm{~N}_{2}$, which also showed lower cell densities (Fig. 2), likely due to a greater redirection of electrons to $\mathrm{H}_{2}$ rather than to biosynthesis, the major $R$. palustris electron sink when nitrogen is abundant (McKinlay et al., 2014).

To determine how heterogeneous environments affected coculture trends under $\mathrm{N}_{2}$ limitation, we performed serial transfers of cocultures grown under static conditions with either $100 \%$ or $18 \% \mathrm{~N}_{2}$ in the headspace, every 2 or 4 weeks, respectively. These longer incubation times were necessary to achieve similar final cell densities between shaking and static environments. Static cocultures with $100 \% \mathrm{~N}_{2}$ had higher $\mathrm{H}_{2}$ yields than shaken cocultures with $100 \% \mathrm{~N}_{2}$ (Fig. 5A). This was expected given that an $R$. palustris subpopulation was experiencing $\mathrm{N}_{2}$ limitation (Eq 1 vs 2). Supplying only $18 \% \mathrm{~N}_{2}$ in static cocultures amplified this trend further (Fig. 5A). In agreement with prior simulations (Supporting Information Fig. S1A), R. palustris growth yields remained similar or increased in response to $\mathrm{N}_{2}$ limitation whereas E. coli growth yields decreased (Fig. 5B). Coexistence was maintained over serial transfers regardless of $\mathrm{N}_{2}$ availability (Fig. 5B). Collectively, these data demonstrate the robustness of our coculture to low $\mathrm{NH}_{4}{ }^{+}$cross-feeding levels in both homogenous and heterogeneous environments.

\section{Fermentation products from maintenance metabolism are crucial for coexistence at low}

cross-feeding levels. In coculture, $R$. palustris growth yields depend on carbon acquisition from E. coli. The relative consistency of $R$. palustris final cell densities despite lower $E$. coli cell densities during $\mathrm{N}_{2}$ limitation (Fig. 5) led us to hypothesize that fermentation associated with $E$. coli maintenance metabolism could be sustaining $R$. palustris during $\mathrm{N}_{2}$ limitation. By this hypothesis, $\mathrm{NH}_{4}{ }^{+}$-limited $E$. coli would grow at a slower rate but would continue to use 
fermentation for maintenance energy; consequently, $R$. palustris would receive a slower but continuous supply of organic acids for growth and $\mathrm{N}_{2}$ fixation. Ultimately, E. coli would assimilate less glucose, as a larger proportion would be used for maintenance, whereas $R$. palustris would receive a similar or even greater amount of carbon from E. coli. This hypothesis in turn implies that fermentative maintenance metabolism by $E$. coli is important for sustaining R. palustris metabolism and thereby coculture viability during $\mathrm{N}_{2}$ limitation.

To empirically test whether fermentative maintenance metabolism can support $R$. palustris growth, we first examined the most extreme condition by completely preventing $E$. coli growth. To prevent $E$. coli growth we made an $E$. coli histidine auxotroph ( $\Delta \mathrm{HisB})$. Our coculture medium does not contain amino acids, so E. coli $\Delta$ HisB cannot grow regardless of $\mathrm{NH}_{4}{ }^{+}$cross-feeding. In cocultures with $E$. coli $\Delta$ HisB, glucose was slowly consumed, the $E$. coli $\Delta$ HisB cell density declined, and the R. palustris cell density increased (Fig. 6A). These results suggested that fermentative maintenance metabolism supported R. palustris growth. However, metabolism of cellular material released by lysed cells can be important for maintaining microbial populations through periods of starvation (Finkel, 2006; Rozen et al., 2009). Therefore, we also considered cell lysis of $E$. coli $\Delta \mathrm{HisB}$ as a carbon source for $R$. palustris. We estimated how much carbon could be released from E. coli cell lysis based on the observed decline in CFUs and elemental compositions of each bacterium (see Methods). Our estimates suggest that all of the carbon from dead $E$. coli cells could only account for $\sim 0.4 \%$ of the carbon required for the amount of $R$. palustris growth observed (Fig. 6B). In contrast, there was more than enough carbon from the glucose consumed in coculture to account for all the R. palustris biomass observed (Fig. 6B). We therefore concluded that fermentative maintenance metabolism can contribute to the cross-feeding of carbon within the mutualism. 
Based on the above result we reasoned that fermentative maintenance metabolism was also likely contributing to coexistence in $\mathrm{N}_{2}$-limited cocultures with wild-type E. coli. However, gauging the impact of fermentative maintenance metabolism during partial starvation conditions is experimentally infeasible as the essential nature of maintenance metabolism means it cannot be genetically eliminated. We therefore turned to modeling to assess the importance of fermentative maintenance metabolism during $\mathrm{N}_{2}$ limitation that permits slow $E$. coli growth. We first modified our previous model (LaSarre et al., 2017) to account for the effects of $\mathrm{N}_{2}$ limitation on the shift from $\mathrm{NH}_{4}{ }^{+}$to $\mathrm{H}_{2}$ production by $R$. palustris (SyFFoN_v2; Supporting Information Methods, Fig. S4-6, and Table S2). The model does not take into account ATP availability for the nitrogenase reactions (Eq.1 and 2); we assumed that ATP is readily available during $\mathrm{N}_{2}$ limitation since $R$. palustris produces high concentrations of $\mathrm{H}_{2}$ when completely starved for nitrogen but provided with light (McKinlay et al., 2014). We then adjusted SyFFoN_v2 parameters to simulate growth rate and metabolite yield data observed at various $\mathrm{N}_{2}$ concentrations (Fig. 3 and Supporting Information Fig. S2 and S4-6). In doing so we found that parameters based on E. coli monoculture data (LaSarre et al., 2017) could not accurately simulate coculture growth rates observed at low $\mathrm{N}_{2}$ concentrations. Rather, E. coli maintenance metabolism had to be increased by up to two-orders of magnitude to more accurately simulate empirical growth rates (Fig. 3B and Supporting Information Table S2). The need for these changes to more accurately simulate observed trends suggests that $R$. palustris consumption of fermentation products pulls $E$. coli fermentation by minimizing end-product inhibition, analogous to what has been observed in other fermentative cross-feeding systems (Iannotti et al., 1973; Hillesland and Stahl, 2010). SyFFoN_v2 accurately predicted $\mathrm{H}_{2}$ yields (Fig. 3A), normalized growth rates (Fig. 3B), and product yields (Supporting Information Fig. S2) between 
$15 \%$ and $100 \% \mathrm{~N}_{2}$. At $\mathrm{N}_{2}$ levels below $15 \%$, R. palustris likely undergoes a starvation response resulting in physiological effects that our model does not predict. We also verified that SyFFoN_v2 could reproduce trends from our previous study (LaSarre et al., 2017), namely the effects of added $\mathrm{NH}_{4}{ }^{+}$(Supporting Information Fig. S7) and varying the R. palustris $\mathrm{NH}_{4}{ }^{+}$ excretion levels (Supporting Information Fig. S1A).

To examine how fermentative maintenance metabolism influenced this mutualism, we used SyFFoN_v2 to simulate the effect of $\mathrm{N}_{2}$ limitation on population dynamics in the presence or absence of $E$. coli maintenance metabolism (Fig. 7). With E. coli maintenance metabolism included, the model predicted that mutualistic growth would be sustained even as $\mathrm{N}_{2}$ concentrations approached zero. E. coli final cell densities were predicted to decline as $\mathrm{N}_{2}$ levels fall below $\sim 30 \%$ while $R$. palustris final cell densities would decline as $\mathrm{N}_{2}$ levels fall below $\sim 20 \%$ (Fig. 7A). In the absence of E. coli maintenance metabolism, simulations predicted a truncated range of $\mathrm{N}_{2}$ concentrations that would support coculture growth (Fig. 7B). In fact, the simulations suggested that $E$. coli maintenance metabolism is necessary at $\mathrm{N}_{2}$ concentrations where we observed reproducible coculture growth trends (Fig. 7). The model predicted similar trends when $\mathrm{NH}_{4}{ }^{+}$excretion levels were varied in place of $\mathrm{N}_{2}$ availability (Supporting Information Fig. S1).

A closer inspection of simulated cross-feeding levels revealed why coculture growth at low $\mathrm{N}_{2}$ concentrations (or low $\mathrm{NH}_{4}{ }^{+}$cross-feeding levels) required fermentative maintenance metabolism. At high $\mathrm{N}_{2}$ levels $\left(100 \% \mathrm{~N}_{2}\right)$, growth-coupled fermentation alone is sufficient to support coculture growth, as any increase in populations results in progressively more metabolites exchanged over time (Supporting Information Fig. S8A). However, near the transitional $\mathrm{N}_{2}$ concentration where coculture growth is predicted to fail in the absence of 
fermentative maintenance metabolism $\left(28 \% \mathrm{~N}_{2}\right)$, metabolite excretion levels decrease as populations grow, resulting in continuously less essential resources for subsequent generations despite available glucose; in other words, cross-feeding spirals into a cycle of diminishing returns (Supporting Information Fig. S8B). Our data indicate that fermentative maintenance metabolism can circumvent diminishing returns. Fermentation products will always be produced, and thus $R$. palustris will eventually grow to a density that collectively excretes sufficient $\mathrm{NH}_{4}{ }^{+}$ to allow for $E$. coli growth. Indeed, when $E$. coli maintenance metabolism is included at $28 \% \mathrm{~N}_{2}$, growth-independent cross-feeding by E. coli stimulates sufficient reciprocal $\mathrm{NH}_{4}{ }^{+}$excretion to sustain coculture growth (Supporting Information Fig. S8C). These simulations strongly suggest that fermentative maintenance metabolism permits cooperative growth at low $\mathrm{NH}_{4}{ }^{+}$excretion levels that would otherwise be insufficient.

\section{E. coli maintenance metabolism prevents cooperative growth at high $E$. coli cell densities.}

On a per cell basis, fermentation product excretion due to maintenance metabolism is considerably slower than that associated with growth (Russell and Cook, 1995). However, we reasoned that a high E. coli cell density could amplify this low rate such that organic acid production would be substantial at a population level. We previously demonstrated that dosedependent toxicity governs mutualism dynamics in our coculture; specifically, organic acids play a beneficial role as a carbon source for R. palustris, but a detrimental role when they accumulate enough to acidify the medium (LaSarre et al., 2017). Thus, we hypothesized that if $E$. coli cell densities were sufficiently high, the collective fermentation rate attributed to maintenance metabolism alone might destabilize the mutualism by producing organic acids faster than the smaller R. palustris population could consume them, resulting in growth-inhibiting acidification. 
To test this hypothesis, we first simulated coculture growth from different initial species densities using SyFFoN_v2. The model correctly predicted that a common equilibrium would be reached from a wide range of initial E. coli densities (Fig. 8A) (LaSarre et al., 2017). However, in agreement with our hypothesis, the model also predicted a maximum initial E. coli density that would allow cooperative growth (Fig. 8A). An upper limit was experimentally verified, albeit at a lower $E$. coli density than what was predicted (Fig. 8A). At an initial E. coli density of $\sim 2 \times 10^{9}$ $\mathrm{CFU} / \mathrm{ml}$, the $\mathrm{pH}$ reached acidic levels known to prevent $R$. palustris growth and metabolism (Fig. 8A) (LaSarre et al., 2017). As a result, neither species' population increased (Fig. 8A). These results contradicted predictions when maintenance metabolism was omitted from the model, as there was no predicted initial E. coli density that would prevent cooperative growth (Fig. 8B).

While SyFFoN_v2 qualitatively predicted that the maintenance metabolism from high initial $E$. coli cell density would lead to growth-inhibiting acidification, it was quantitatively inaccurate (Fig. 8A). This prediction used maintenance metabolism rates that were based on data from $E$. coli cells that had been adapted to non-growing conditions for 1 day. However, fermentation rates during days 1-7 were 2- to 10 -fold slower than those observed over days $0-1$; thus, the inaccuracy could stem from an underestimation of the early maintenance fermentation rate (Supporting Information Fig. S9). To explore this possibility, we calculated the level of organic acids that would accumulate in $24 \mathrm{~h}$ for a given initial $E$. coli cell density using fermentation rates determined during the first day of $E$. coli cell suspensions (Supporting Information Fig. S9). These organic acid levels were then entered as initial values into SyFFoN_v2 to account for organic acid production during the first $24 \mathrm{~h}$, and batch cultures were then simulated with all the other parameter values the same as used for Fig. 8A. The simulations 
indicate that when the initial E. coli cell density is low, a rapid early rate of organic acid production leads to negligible organic acid accumulation and thus the population trends are unaffected (Fig. 8C). However, when the initial E .coli cell density is high, a rapid early rate of organic acid production can lead to substantial organic acid accumulation and better approximate the upper E. coli cell density that would prevent coculture growth (Fig 8C). A potentially compounding factor to help explain the discrepancy between simulated and observed inhibitory initial E. coli levels is that once inhibitory acid levels are reached, cell death will likely occur; SyFFoN_v2 does not simulate cell death.

SyFFoN_v2 simulations also indicated that it is the initial E. coli cell density rather than the initial species ratio that determines if coculture growth will be prevented through dosedependent toxicity; the inhibitory effect of high initial E. coli cell densities could be offset by a high initial $R$. palustris cell density enabling organic acid consumption at a rate sufficient to hamper accumulation (Fig. 8D). However, simulations suggest that an initial R. palustris concentration of $10^{10}$ cells / $\mathrm{ml}$ would be required to fully offset the acidification from an initial E. coli cell density of $10^{9}$ cells / $\mathrm{ml}$, mainly because $\mathrm{NH}_{4}{ }^{+}$cross-feeding by $R$. palustris would stimulate E. coli growth and thereby accelerate fermentation and organic acid accumulation. Thus, while E. coli maintenance metabolism is a stabilizing factor at low $\mathrm{NH}_{4}{ }^{+}$exchange levels, it can also serve to destabilize the mutualism at high E. coli densities.

\section{Discussion}

In this study, we demonstrated that cross-feeding stemming from maintenance metabolism can circumstantially impede or promote mutualism. We found that mutualism destabilization by maintenance metabolism depends on dose-dependent toxicity of a cross-fed 
nutrient. Specifically, destabilization occurs when a maintenance metabolism leads to the accumulation of cross-fed nutrients to levels that inhibit growth of the partner species.

Destabilization of a natural mutualism linked to maintenance metabolism would require specific conditions. In our system, organic acid toxicity is relatively low, in part due to the buffered medium. Thus, an extremely high initial E. coli cell density was required before fermentative maintenance metabolism could inhibit cooperative growth via culture acidification. However, inhibitory effects stemming from maintenance metabolism could occur at cell densities relevant to natural systems in a less well-buffered system or if the toxicity of the cross-fed metabolite was intrinsically high. For example, notoriously toxic compounds like cyanide (Harris and Knowles, 1983) and antibiotics (Dantas et al., 2008; Barnhill et al., 2010) can serve as nutrients for some bacteria as long as concentrations remain low.

While the likelihood of mutualism destabilization linked to maintenance metabolism is difficult to gauge, promotion of cross-feeding relationships by maintenance metabolism is likely widespread. Vast areas of the Earth's biosphere are limited for key nutrients (Lever et al., 2015), and it is well appreciated that nutrient limitation can promote cross-feeding in natural environments (Hom and Murray, 2014; Seth and Taga, 2014). However, it is poorly understood how established mutualisms respond to perturbations that limit cross-feeding itself. It is thought that exchange rates within obligate mutualisms must be sufficient to support sustained growth of both species in order to avoid eventual extinction (Shou et al., 2007). Our results demonstrate that cross-feeding associated with maintenance metabolism can ease this requirement. In our system, fermentation product excretion from E. coli maintenance metabolism can preserve the mutualism amid unfavorable $\mathrm{NH}_{4}{ }^{+}$exchange levels by continually cross-feeding organic acids. This persistent cross-feeding stimulates $R$. palustris growth and $\mathrm{NH}_{4}{ }^{+}$excretion, thereby lifting 
both species out of starvation. In other words, maintenance metabolism allows cross-feeding to persist and facilitates cooperative success over an extended range of excretion levels compared to metabolites whose excretion depends on growth. Given that the majority of microbes in natural environments are in a state of dormancy or low metabolic activity (Hoehler and Jørgensen, 2013; Lever et al., 2015; Jørgensen and Marshall, 2016), we postulate that metabolite release is more likely to be growth-independent. As such, maintenance metabolism could better serve to initiate and maintain mutualisms in natural environments. Separately, although fermentative maintenance metabolism promoted partner growth under our study conditions, it is imaginable that mutualistic cross-feeding could purely support maintenance energy requirements in some cases, thereby promoting survival until nutrient availability improves.

Organic acids, and other fermentation products, are important metabolic intermediates in anaerobic food webs (McInerney et al., 2008; Jørgensen and Marshall, 2016). Fermentative maintenance metabolism could therefore play an important role under nutrient-limiting conditions by sustaining mutualistic relationships with acetogens, methanogens, photoheterotrophs, and anaerobically respiring microbes that rely on fermentation products for carbon and electrons. However, contributions of maintenance metabolism to mutualisms need not be restricted to fermentation nor to natural environments. Generation of maintenance energy is essential. Thus, mutualistic relationships encompassing diverse lifestyles could conceivably be preserved at low metabolic rates, provided that the limiting nutrient(s) still permits the excretion of factors required to sustain partner viability. Forcing a partner into a primary state of maintenance metabolism by limiting cross-feeding could also conceivably be a selfish strategy by which a partner could capitalize on resources that are limiting to both partners without severing essential mutualistic ties. Understanding maintenance metabolism-linked cross-feeding 
could also benefit industrial bioprocesses, which commonly use growth-limiting conditions to boost product yields. Indeed, growth-independent cross-feeding helped sustain our coculture during $\mathrm{N}_{2}$-limiting conditions under which the highest $\mathrm{H}_{2}$ yields were observed (Fig. 4 and 5). Applications of microbial consortia for industrial processes is gaining interest (Sabra et al., 2010) but the effects of nutrient limitation have yet to be investigated. Clearly, the role of maintenance metabolism in fostering microbial cooperation deserves closer appraisal in both natural and applied systems.

\section{Experimental Procedures}

Strains, plasmids, and growth conditions. Strains are listed in Supporting Information Table S1. E. coli and R. palustris were cultivated on Luria-Burtani (LB) agar or defined mineral (PM) (Kim and Harwood, 1991) agar with $10 \mathrm{mM}$ succinate, respectively. For determining colony forming units (CFU), LB agar or PM agar minus $\left(\mathrm{NH}_{4}\right)_{2} \mathrm{SO}_{4}$ were used for $E$. coli and $R$. palustris, respectively. Cultures were grown in 10-mL of defined M9-derived coculture medium (MDC) (LaSarre et al., 2017) in 27-mL anaerobic test tubes. The medium was made anaerobic by bubbling with $\mathrm{N}_{2}$, sealed with rubber stoppers and aluminum crimps, and then autoclaved. After autoclaving, MDC was supplemented with cation solution $\left(1 \% \mathrm{v} / \mathrm{v} ; 100 \mathrm{mM} \mathrm{MgSO}_{4}\right.$ and $\left.10 \mathrm{mM} \mathrm{CaCl}_{2}\right)$ and glucose $(25 \mathrm{mM})$. For defined $\mathrm{N}_{2}$ concentrations, the medium was bubbled with argon and after autoclaving defined volumes of $\mathrm{N}_{2}$ were injected through a 0.2 micron syringe filter. All cultures were grown at $30^{\circ} \mathrm{C}$ either laying horizontally under a $60 \mathrm{~W}$ incandescent bulb with shaking at $150 \mathrm{rpm}$ (shaking conditions) or upright without agitation (static conditions). Static cultures were only mixed for sampling upon inoculation and at the termination of an experiment. Thus, growth rates were not measured under static conditions. 
Starter cultures were inoculated with $200 \mu \mathrm{L}$ MDC containing a suspension of a single colonies of each species. Test cocultures were inoculated using a 1\% inoculum from starter cocultures except for cocultures with the $E$. coli $\Delta$ HisB strain. For these cocultures, E. coli $\Delta$ HisB and $R$. palustris Nx starter monocultures were grown to equivalent cell densities, washed twice with MDC, and inoculated at a 1:1 ratio for a total of $1 \%$ inoculum. For serial transfers, cocultures were incubated for either one week (shaking), two weeks $\left(100 \% \mathrm{~N}_{2} ;\right.$ static), or four weeks (18\% $\mathrm{N}_{2}$; static) before transferring a $1 \%$ stationary phase inoculum to fresh medium.

Generation of the $\boldsymbol{E}$. coli $\Delta$ HisB mutant. P1 transduction was used to introduce $\Delta h i s B:: K m$ from the Keio strain JW2004-1 (Baba et al., 2006) into MG1655 as described (Thomason et al., 2007). The $\Delta h i s B:: K m$ mutation was confirmed by PCR and histidine auxotrophy was verified by a requirement for histidine for growth in M9 medium.

Analytical procedures. Cell density was assayed by optical density at $660 \mathrm{~nm}\left(\mathrm{OD}_{660}\right)$ using a Genesys 20 visible spectrophotometer (Thermo-Fisher, Waltham, MA, USA). Growth curve readings were taken in culture tubes without sampling. Specific growth rates were determined by fitting an exponential trend line to measurements between $0.1-1.0 \mathrm{OD}_{660}$ where there is linear correlation between cell density and $\mathrm{OD}_{660}$. Final $\mathrm{OD}_{660}$ measurements (i.e., the maximum $\mathrm{OD}_{660}$ value corresponding to the cessation of growth) were taken in cuvettes wherein samples were diluted into the linear range as necessary. To compare cell densities between growth conditions, CFUs were converted into growth yields (CFUs per $\mu$ mol glucose consumed), as $\mathrm{N}_{2}$ limitation prevented complete glucose consumption during the assay period. $\mathrm{H}_{2}$ and $\mathrm{N}_{2}$ were quantified using a Shimadzu (Kyoto, Japan) gas chromatograph with a thermal conductivity detector as described (Huang et al., 2010). Glucose, organic acids, and ethanol were quantified using a 
Shimadzu high-performance liquid chromatograph as described (McKinlay et al., 2005). $\mathrm{NH}_{4}{ }^{+}$ was quantified using an indophenol colorimetric assay as described (LaSarre et al., 2017). Calculations of carbon release due to lysis of $E$. coli $\Delta H i s B$. To estimate carbon released due to $E$. coli lysis and carbon assimilated by $R$. palustris, $\mathrm{CFU} / \mathrm{ml}$ values were first used to estimate OD values using a conversion factor of $5 \times 10^{8} \mathrm{CFU} / \mathrm{ml} / \mathrm{OD}$ for both species based on experimental standard curves. OD values were then converted into mg of dry cell weight $(\mathrm{DCW}) / \mathrm{L}$ and then to $\mathrm{mM}$ carbon using published conversion factors and molecular weights from elemental compositions for $E$. coli $\left(351 \mathrm{mg} / \mathrm{L} / \mathrm{OD}, \mathrm{CH}_{1.77} \mathrm{O}_{0.49} \mathrm{~N}_{0.24}\right)$ (Neidhardt, 1987; Stockar and Liu, 1999) and $R$. palustris (625 mg/L/OD, $\left.\mathrm{CH}_{1.8} \mathrm{~N}_{0.18} \mathrm{O}_{0.38}\right)$ (McKinlay and Harwood, 2010). Dividing these values of $E$. coli carbon by R. palustris carbon gives the fraction of R. palustris growth that could be supported by E. coli lysis. This fraction represents an upper bound, as it is based on the liberal assumption that $R$. palustris can assimilate all carbon from a lysed E. coli cell.

SyFFoN_v2 model. SyFFoN_v2 was modified from a previous version of the model (LaSarre $e t$ al., 2017) as described in the Supporting Information. Default parameter values and descriptions of functions are in Supporting Information Table S2 and Fig. S4-6). SyFFoN_v2 runs in R studio and is available for download at: https://github.com/McKinlab/Coculture-Mutualism.

\section{Acknowledgements}

We thank David Kysela and Amelia Randich for discussions on the model name, SyFFoN. We also thank anonymous reviewers for insightful comments, including the potential for withholding resources as a selfish strategy. This work was supported in part by the U.S. Department of Energy, Office of Science, Office of Biological and Environmental Research, under Award 
Number DE-SC0008131, by the U.S. Army Research Office, grant W911NF-14-1-0411, and by the Indiana University College of Arts and Sciences. The authors declare no conflict of interest.

\section{References}

Baba, T., Ara, T., Hasegawa, M., Takai, Y., Okumura, Y., Baba, M., et al. (2006) Construction of Escherichia coli K-12 in-frame, single-gene knockout mutants: the Keio collection. Mol. Syst. Biol. 2: 2006.0008.

Barnhill, A.E., Weeks, K.E., Xiong, N., Day, T.A., and Carlson, S.A. (2010) Identification of multiresistant Salmonella isolates capable of subsisting on antibiotics. Appl. Environ. Microbiol. 76: 2678-2680.

Chubiz, L.M., Granger, B.R., Segrè, D., and Harcombe, W.R. (2015) Species interactions differ in their genetic robustness. Front. Microbiol. 6: 1-9.

Dantas, G., Sommer, M.O.A., Oluwasegun, R.D., and Church, G.M. (2008) Bacteria Subsisting on Antibiotics. Science. 320: 100-104.

Ding, J., Liu, B.F., Ren, N.Q., Xing, D.F., Guo, W.Q., Xu, J.F., and Xie, G.J. (2009) Hydrogen production from glucose by co-culture of Clostridium butyricum and immobilized Rhodopseudomonas faecalis RLD-53. Int. J. Hydrogen Energy. 34: 3647-3652.

Durham, B.P., Sharma, S., Luo, H., Smith, C.B., Amin, S.A., Bender, S.J., et al. (2015) Cryptic carbon and sulfur cycling between surface ocean plankton. Proc. Natl. Acad. Sci. 112: 453457.

Fang, H., Zhu, H., and Zhang, T. (2006) Phototrophic hydrogen production from glucose by pure and co-cultures of Clostridium butyricum and Rhodobacter sphaeroides. Int. J. Hydrogen Energy. 31: 2223-2230. 
Ferenci, T. (2001) Hungry bacteria - definition and properties of a nutritional state. Environ. Microbiol. 3: 605-611.

Finkel, S.E. (2006) Long-term survival during stationary phase: evolution and the GASP phenotype. Nat.Rev.Microbiol. 4: 113-120.

Flint, H.J., Duncan, S.H., Scott, K.P., and Louis, P. (2007) Interactions and competition within the microbial community of the human colon: Links between diet and health: Minireview. Environ. Microbiol. 9: 1101-1111.

Hammer, N.D., Cassat, J.E., Noto, M.J., Lojek, L.J., Chadha, A.D., Schmitz, J.E., et al. (2014) Inter- and intraspecies metabolite exchange promotes virulence of antibiotic-resistant Staphylococcus aureus. Cell Host Microbe. 16: 531-537.

Harcombe, W. (2010) Novel cooperation experimentally evolved between species. Evolution. 64: $2166-2172$.

Harcombe, W.R., Riehl, W.J., Dukovski, I., Granger, B.R., Betts, A., Lang, A.H., et al. (2014) Metabolic resource allocation in individual microbes determines ecosystem interactions and spatial dynamics. Cell Rep. 7: 1104-1115.

Harris, R. and Knowles, C.J. (1983) Isolation and growth of a Pseudomonas species that utilizes cyanide as a source of nitrogen. J. Gen. Microbiol. 129: 1005-1011.

Hillesland, K.L. and Stahl, D. a (2010) Rapid evolution of stability and productivity at the origin of a microbial mutualism. Proc. Natl. Acad. Sci. U. S. A. 107: 2124-9.

Hoehler, T.M. and Jørgensen, B.B. (2013) Microbial life under extreme energy limitation. Nat. Rev. Microbiol. 11: 83-94.

Hoffman, B.M., Lukoyanov D., Dean, D.R., and Seefeldt, L.C. (2013) Nitrogenase: a draft mechanism. Acc. Chem. Res. 46: 587-595. 
Hom, E.F.Y. and Murray, A.W. (2014) Niche engineering demonstrates a latent capacity for fungal-algal mutualism Science. 345: 94-98.

Huang, J.J., Heiniger, E.K., McKinlay, J.B., and Harwood, C.S. (2010) Production of hydrogen gas from light and the inorganic electron donor thiosulfate by Rhodopseudomonas palustris. Appl. Environ. Microbiol. 76: 7717-22.

Iannotti, E.L., Kafkewit, D., Wolin, M.J., and Bryant, M.P. (1973) Glucose Fermentation Products of Ruminococcus albus grown in continuous culture with Vibrio succinogenes Changes caused by interspecies transfer of $\mathrm{H}_{2}$. J. Bacteriol. 114: 1231-1240.

Jørgensen, B.B. and Marshall, I.P.G. (2016) Slow Microbial Life in the Seabed. Ann. Rev. Mar. Sci. 8: 311-332.

Kim, H.J., Boedicker, J.Q., Choi, J.W., and Ismagilov, R.F. (2008) Defined spatial structure stabilizes a synthetic multispecies bacterial community. Proc. Natl. Acad. Sci. U. S. A. 105: $18188-18193$.

Kim, M.K. and Harwood, C.S. (1991) Regulation of benzoate-CoA ligase in Rhodopseudomonas palustris. FEMS Microbiol. Letters. 83: 199-203.

LaSarre, B., McCully, A.L., Lennon, J.T., and McKinlay, J.B. (2017) Microbial mutualism dynamics governed by dose-dependent toxicity of cross-fed nutrients. ISME J. 11: 337-348.

Lee, I.H., Fredrickson, A.G., and Tsuchiya, H.M. (1976) Dynamics of mixed cultures of Lactobacillus plantarum and Propionibacterium shermanii. Biotechnol. Bioeng. 18: 51326.

Lever, M.A., Rogers, K.L., Lloyd, K.G., Overmann, J., Schink, B., Thauer, R.K., et al. (2015) Life under extreme energy limitation: A synthesis of laboratory- and field-based investigations. FEMS Microbiol. Rev. 39: 688-728. 
Lindemann, S.R., Bernstein, H.C., Song, H.-S., Fredrickson, J.K., Fields, M.W., Shou, W., et al. (2016) Engineering microbial consortia for controllable outputs. ISME J. 10: 2077-2084.

McInerney, M.J., Sieber, J.R., and Gunsalus, R.P. (2010) Syntrophy in anaerobic global carbon cycles. Curr. Opin. Biotechnol. 20: 623-632.

McInerney, M.J., Struchtemeyer, C.G., Sieber, J., Mouttaki, H., Stams, A.J.M., Schink, B., et al. (2008) Physiology, ecology, phylogeny, and genomics of microorganisms capable of syntrophic metabolism. Ann. N. Y. Acad. Sci. 1125: 58-72.

McKinlay, J.B. and Harwood, C.S. (2010) Carbon dioxide fixation as a central redox cofactor recycling mechanism in bacteria. Proc. Natl. Acad. Sci. U. S. A. 107: 11669-75.

McKinlay, J.B., Oda, Y., Ruhl, M., Posto, A.L., Sauer, U., and Harwood, C.S. (2014) Nongrowing Rhodopseudomonas palustris increases the hydrogen gas yield from acetate by shifting from the glyoxylate shunt to the tricarboxylic acid cycle. J. Biol. Chem. 4: 19601970.

McKinlay, J.B., Zeikus, J.G., and Vieille, C. (2005) Insights into Actinobacillus succinogenes fermentative metabolism in a chemically defined growth medium. Appl Env. Microbiol. 71: $6651-6656$.

Mee, M.T., Collins, J.J., Church, G.M., and Wang, H.H. (2014) Syntrophic exchange in synthetic microbial communities. Proc. Natl. Acad. Sci. U. S. A. 111: E2149-56.

Megee III, R.D., Drake, J.F., Fredrickson, A.G., and Tsuchiya, H.M. (1972) Studies in intermicrobial symbiosis. Saccharomyces cerevisiae and Lactobacillus casei. Can. J. Microbiol. 18: 1722-1742.

Momeni, B., Chen, C.C., Hillesland, K.L., Waite, A., and Shou, W. (2011) Using artificial systems to explore the ecology and evolution of symbioses. Cell. Mol. Life Sci. 68: 1353- 
1368.

Morris, B.E.L., Henneberger, R., Huber, H., and Moissl-Eichinger, C. (2013) Microbial syntrophy: Interaction for the common good. FEMS Microbiol. Rev. 37: 384-406.

Neidhardt, F.C. (1987) Escherichia coli and Salmonella typhimurium Cellular and Molecular Biology. American Society for Microbiology, Washington, DC.

Odom, J.M. and Wall, J.D. (1983) Photoproduction of $\mathrm{H}_{2}$ from cellulose by an anaerobic bacterial coculture. Appl Env. Microbiol. 45: 1300-1305.

Pande, S., Merker, H., Bohl, K., Reichelt, M., Schuster, S., de Figueiredo, L.F., et al. (2014) Fitness and stability of obligate cross-feeding interactions that emerge upon gene loss in bacteria. ISME J. 8: 953-62.

Ponomarova, O. and Patil, K.R. (2015) Metabolic interactions in microbial communities: Untangling the Gordian knot. Curr. Opin. Microbiol. 27: 37-44.

Ramsey, M.M. and Whiteley, M. (2009) Polymicrobial interactions stimulate resistance to host innate immunity through metabolite perception. Proc. Natl. Acad. Sci. U. S. A. 106: 15781583.

Rittershaus, E.S.C., Baek, S.H., and Sassetti, C.M. (2013) The normalcy of dormancy: Common themes in microbial quiescence. Cell Host Microbe. 13: 643-651.

Rozen, D.E., Philippe, N., Arjan De Visser, J., Lenski, R.E., and Schneider, D. (2009) Death and cannibalism in a seasonal environment facilitate bacterial coexistence. Ecol. Lett. 12: 3444.

Russell, J.B. and Cook, G.M. (1995) Energetics of bacterial growth: balance of anabolic and catabolic reactions. Microbiol. Rev. 59: 48-62.

Sabra, W., Dietz, D., Tjahjasari, D., and Zeng, A.-P. (2010) Biosystems analysis and engineering 
of microbial consortia for industrial biotechnology. Eng. Life Sci. 10: 407-421.

Seth, E.C. and Taga, M.E. (2014) Nutrient cross-feeding in the microbial world. Front. Microbiol. 5: 350 .

Shou, W., Ram, S., and Vilar, J.M.G. (2007) Synthetic cooperation in engineered yeast populations. Proc. Natl. Acad. Sci. U. S. A. 104: 1877-82.

Stockar, U. Von and Liu, J. (1999) Does microbial life always feed on negative entropy? Thermodynamic analysis of microbial growth. Biochimica et biophysica acta. 1412: 191211.

Stolyar, S., Van Dien, S., Hillesland, K.L., Pinel, N., Lie, T.J., Leigh, J. a, and Stahl, D. a (2007) Metabolic modeling of a mutualistic microbial community. Mol. Syst. Biol. 3: 92.

Summers, Z.M., Fogarty, H.E., Leang, C., Franks, A.E., Malvankar, N.S., and Lovley, D.R. (2010) Direct exchange of electrons within aggregates of an evolved syntrophic coculture of anaerobic bacteria. Science. 330: 1413-5.

Sun, Q., Xiao, W., Xi, D., Shi, J., Yan, X., and Zhou, Z. (2010) Statistical optimization of biohydrogen production from sucrose by a co-culture of Clostridium acidisoli and Rhodobacter sphaeroides. Int. J. Hydrogen Energy 35: 4076-4084.

Thomason, L.C., Costantino, N., and Court, D.L. (2007) E. coli genome manipulation by P1 transduction. Curr. Protoc. Mol. Biol. 1.17.1-1.17.8.

Wanner, U. and Egli, T. (1990) Dynamics of microbial growth and cell composition in batch culture. FEMS Microbiol. Rev. 6: 19-43.

Widder, S., Allen, R.J., Pfeiffer, T., Curtis, T.P., Wiuf, C., Sloan, W.T., et al. (2016) Challenges in microbial ecology: building predictive understanding of community function and dynamics. ISME J. 10: 2557-2568. 


\section{Figure Legends}

Fig. 1. Bi-directional anaerobic cross-feeding between fermentative $E$. coli and phototrophic $R$. palustris Nx. E. coli anaerobically ferments glucose into fermentation products, including the organic acids acetate, lactate, and succinate, which provide essential carbon for $R$. palustris Nx.

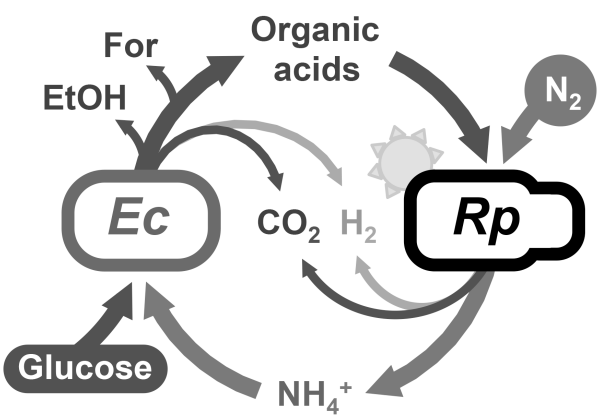
In return $R$. palustris $\mathrm{Nx}$ uses light energy to fix $\mathrm{N}_{2}$ and excrete $\mathrm{NH}_{4}{ }^{+}$, which provides $E$. coli with essential nitrogen. Formate and ethanol, produced by E. coli, and $\mathrm{CO}_{2}$ and $\mathrm{H}_{2}$, produced by both species, accumulate. E. coli fermentation can be growth-independent. Filled bubbles indicate compounds externally added to the coculture.

Fig. 2. Limiting $\mathrm{N}_{2}$ in monoculture results in decreased $\mathrm{NH}_{4}{ }^{+}$excretion. Final cell densities (A) and supernatant $\mathrm{NH}_{4}^{+}$levels (B) in stationary-phase $R$. palustris CGA4004 (Parent) and CGA4005 (Nx) monocultures. R. palustris was cultured in MDC with $5 \mathrm{mM}$ acetate, with a headspace of $100 \% \mathrm{~N}_{2}$ or $18 \% \mathrm{~N}_{2}$, and incubated either horizontally with shaking or upright without agitation (static). Error bars indicate $\mathrm{SD}, \mathrm{n}=3-6$. Different letters indicate statistical differences, $\mathrm{p}<$ 0.0001, determined by one-way ANOVA (DFn, DFd $=4,16 ;(\mathbf{A}) \mathrm{F}=50 ;(\mathbf{B}) \mathrm{F}=269$ ) with Tukey's

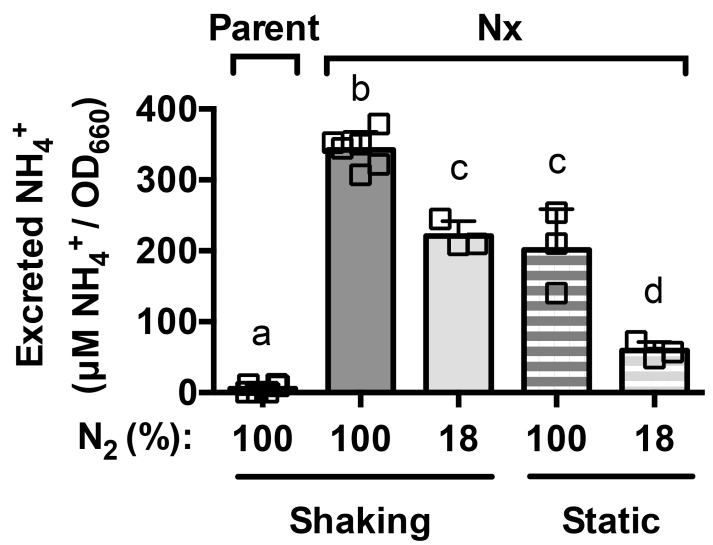
multiple comparisons post test. 
Fig. 3. Cocultures maintain coexistence despite lower $\mathbf{N H}_{4}^{+}$cross-feeding. $\mathrm{H}_{2}$ yields (A) and normalized growth rates $(\mathbf{B})$ of cocultures grown with various $\mathrm{N}_{2}$ concentrations (\% of gas in $17 \mathrm{ml}$ of headspace) under shaking conditions. Circles indicate empirical data. Lines indicate SyFFoN_v2 model predictions. (A) Shaded region indicates low $\mathrm{N}_{2}$ concentrations where empirical trends do not match model predictions. (B) Empirical and simulated growth rates are normalized to the corresponding average measured or simulated growth rate of cocultures with $100 \% \mathrm{~N}_{2}$ (parameter $\left.\mathrm{N}=70 \mathrm{mM}\right)$.
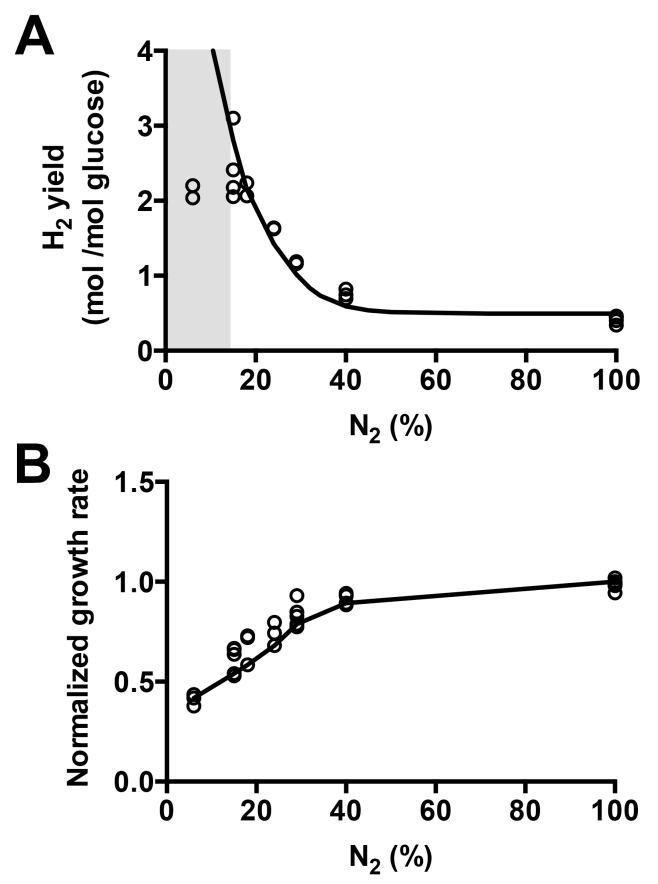
Fig. 4. $\mathrm{N}_{2}$-limited cocultures exhibit stable coexistence and reproducible trends through serial transfers in a well-mixed environment. Species growth yields and final E. coli percentages (A), $\mathrm{H}_{2}$ yields (B), and growth rates $(\mathbf{C})$ from three serial transfers of shaken cocultures grown with $18 \% \mathrm{~N}_{2}$. Transfer 1 was inoculated from a stationary phase starter coculture grown under $100 \% \mathrm{~N}_{2}$ with shaking. Cocultures were serially transferred every 7 days. Error bars indicate 95\% CI, $\mathrm{n}=4$. Shaded horizontal bars indicate $95 \%$ CI for shaken cocultures grown with $100 \% \mathrm{~N}_{2}$ (LaSarre et al., 2017). (A) Growth yields are compared for each species rather than final cell densities to account for incomplete glucose consumption after 1 week in cocultures with $18 \% \mathrm{~N}_{2}$. Final E. coli $(E c)$ percentages are the mean $\pm \mathrm{SD}, \mathrm{n}=4 .{ }^{*}$, statistical difference from $E$. coli percentages in shaken cocultures serially transferred with $100 \% \mathrm{~N}_{2}$ (LaSarre et al., 2017), $\mathrm{p}<0.001$, determined using one-way ANOVA (DFn, DFd =3, 12; F = 13) with Tukey's multiple comparison post test.

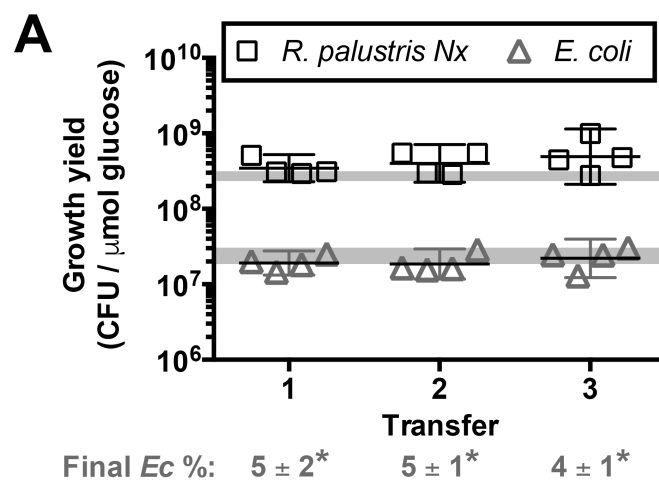

B
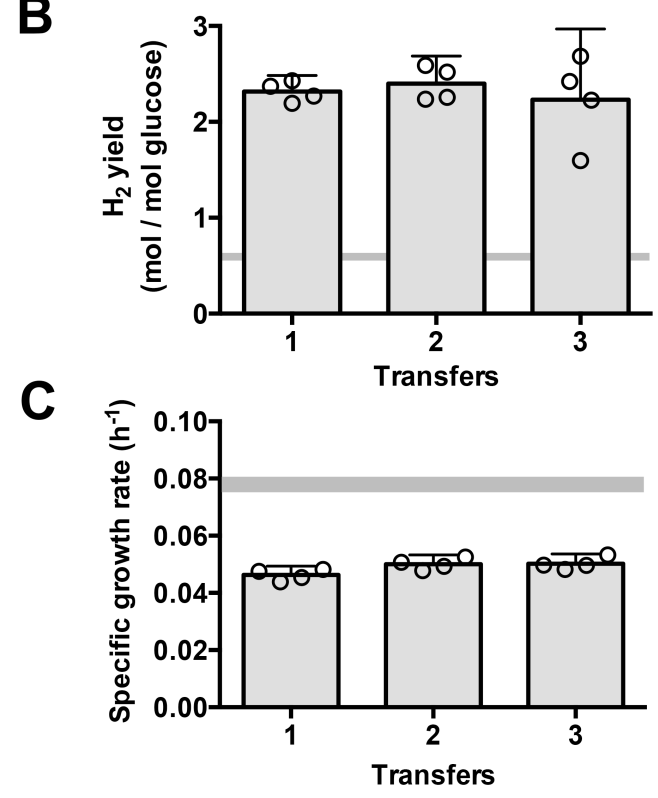
Fig. 5. $\mathrm{N}_{2}$-limited cocultures exhibit stable coexistence and reproducible trends through serial transfers in a heterogeneous environment. $\mathrm{H}_{2}$ yields $(\mathbf{A})$, and individual species growth yields and final E. coli percentages $(\mathbf{B})$ from three serial transfers of static cocultures grown with either $100 \%$ or $18 \% \mathrm{~N}_{2}$. Transfer 1 was inoculated from a stationary phase starter coculture grown under $100 \% \mathrm{~N}_{2}$ with shaking. Static cocultures with $100 \% \mathrm{~N}_{2}$ and $18 \% \mathrm{~N}_{2}$ were serially transferred every 2 and 4 weeks, respectively. Error bars indicate $95 \% \mathrm{CI}, \mathrm{n}=4$. Shaded horizontal bars indicate 95\% CI for shaken cocultures grown with 100\% $\mathrm{N}_{2}$ (LaSarre et al., 2017). (A) Different letters indicate statistical differences, $\mathrm{p}<0.01$, determined by one-way ANOVA (DFn, DFn $=5,18 ; \mathrm{F}=$ 7) with Tukey's multiple comparisons post test. (B) Final E. coli $(E c)$ percentages are the mean $\pm \mathrm{SD}, \mathrm{n}=4$; *statistical difference from E. coli percentages in shaken cocultures serially transferred with $100 \% \quad \mathrm{~N}_{2}$ (LaSarre et al., 2017), $\mathrm{p}<0.0001$, determined using one-way ANOVA $(\mathrm{DFn}, \mathrm{DFn}=3,12 ;(100 \%) \mathrm{F}=34$; $(18 \%) \mathrm{F}=56)$ with Tukey's multiple comparison post test.

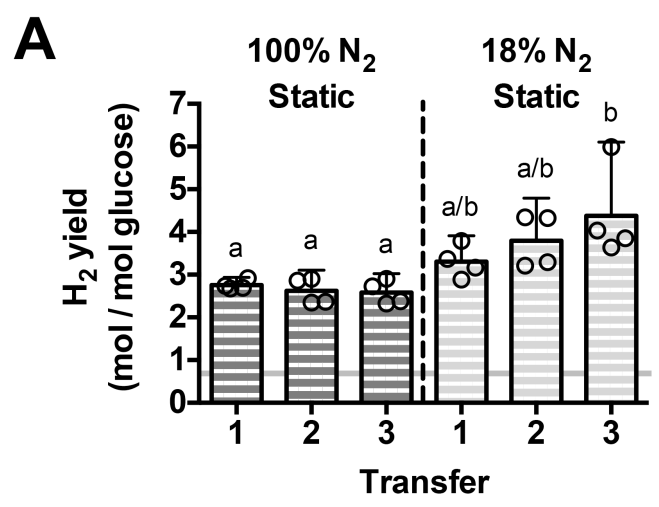

B

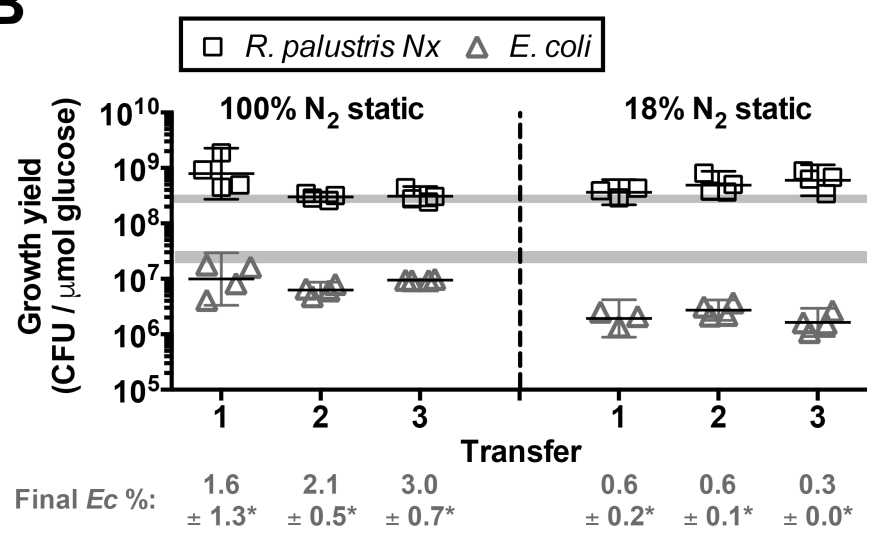


Fig. 6. Fermentative maintenance metabolism facilitates carbon cross-feeding. (A) Timecourse of $E$. coli $\Delta \mathrm{HisB}$ and $R$. palustris cell densities and glucose consumption in coculture.

E. coli $\Delta$ HisB and $R$. palustris were inoculated

at equivalent CFUs/mL. Most error bars are too small to see. Error bars indicate SD, $n=3$. (B) Estimated carbon for glucose consumption, E. coli lysis, and $R$. palustris growth based on the data in (A). Conversion of $\mathrm{CFU} / \mathrm{ml}$ to $\mathrm{mM}$ carbon is described in the Methods. Error bars indicate SD, $\mathrm{n}=3$. Numerical values are averages $\pm \mathrm{SD}$.
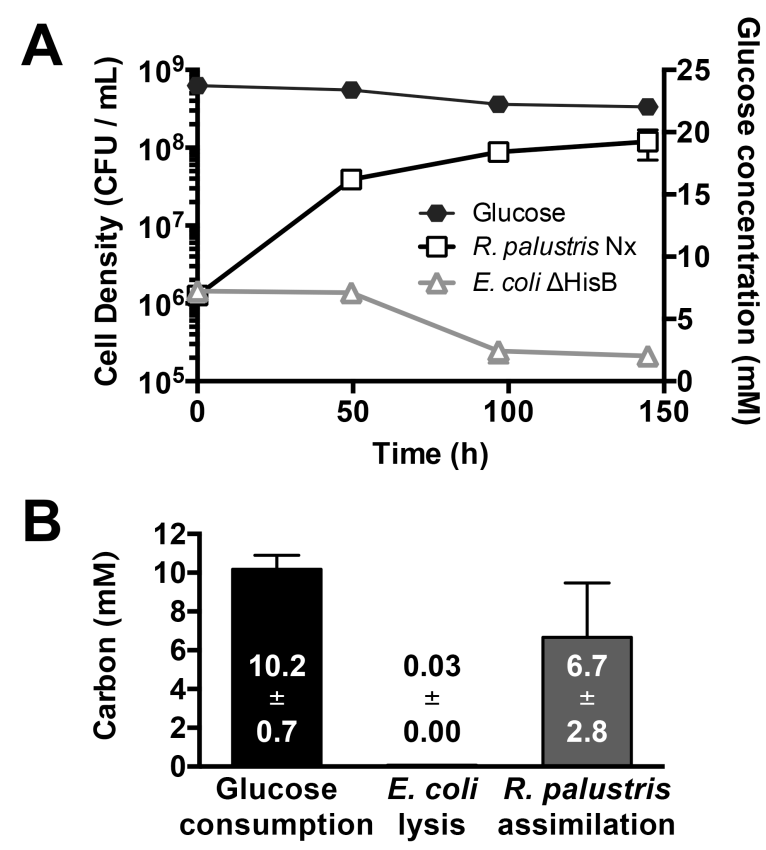
Fig. 7. Fermentative maintenance metabolism permits coexistence at low $\mathrm{NH}_{4}{ }^{+}$cross-feeding

levels. Simulated cell densities (lines) from cocultures grown with different $\mathrm{N}_{2}$ concentrations

when maintenance metabolism is included (A)

or omitted (B) from the model. $\mathrm{Ec}_{i \text { sim }}$ and $\mathrm{Rp}_{i}$

sim, initial simulated E. coli $(E c)$ and $R$.

palustris $(R p)$ cell densities; $\mathrm{Ec}_{f}$ sim and $\mathrm{Rp}_{f}$ sim,

final simulated E. coli and R. palustris cell

densities. Symbols are empirical CFU/mL data for E. coli $\left(\mathrm{Ec}_{f}\right.$ emp $)$ and R. palustris $\left(\mathrm{Rp}_{f}\right.$

emp) from 7 day samples from shaken cocultures with $6 \%, 18 \%, 40 \%$ or $100 \% \mathrm{~N}_{2}$.

The same empirical data is overlaid on both panels $(n=3)$.
A

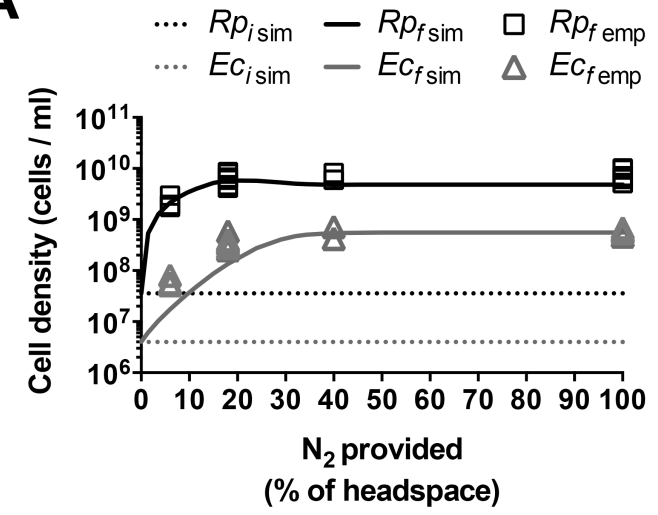

B

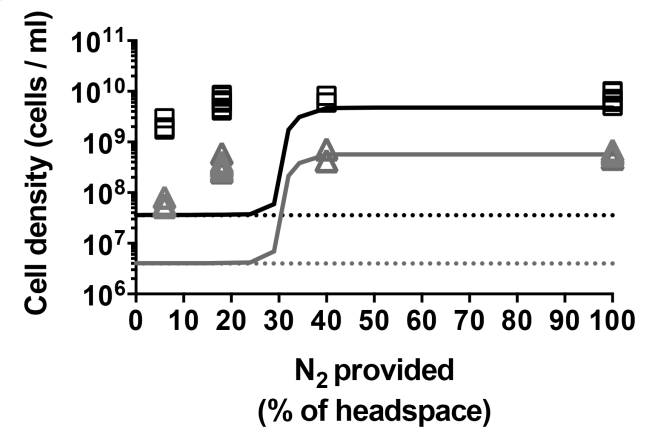

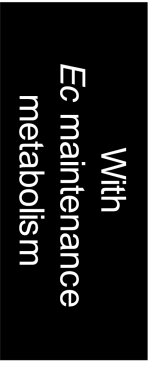

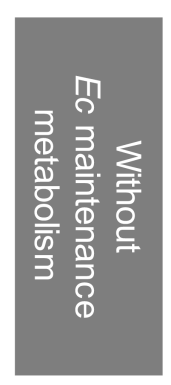


Figure 8. Fermentative maintenance metabolism prevents coculture growth at high $E$. coli cell densities. (A-C) Simulated changes in $E$. coli $\left(E c_{\text {sim }}\right)$ and $R$. palustris $\left(R p_{\text {sim }}\right)$ cell densities (lines) in cocultures grown with $100 \% \mathrm{~N}_{2}$ with different initial E. coli cell densities when maintenance metabolism is included $(\mathbf{A}, \mathbf{C})$ or omitted $(\mathbf{B})$ from the model. The simulated initial R. palustris cell density was $10^{7}$ cells $/ \mathrm{ml}$. (A, C) These two simulations were identical except that (C) included initial consumable organic acids [C] and formate [f] levels that were calculated by multiplying the initial E. coli cell density by the $0-1$ day maintenance fermentation rate shown in Supporting Information Fig. S9 x 24 h. Symbols are empirical CFU/mL data for E. coli $\left(E c_{\mathrm{emp}}\right)$ and $R$. palustris $\left(R p_{\text {emp }}\right)$ from cocultures with different initial $E$. coli cell densities and an average initial $R$. palustris density of $2.4 \times 10^{7} \pm 0.3 \times 10^{7} \mathrm{CFU} / \mathrm{ml}$. Experimental cell densities were determined $10 \mathrm{~d}$ after coculture inoculation. The measured coculture $\mathrm{pH}$ after $10 \mathrm{~d}$ is also shown. (D) Simulated E. coli and R. palustris growth when cocultures grown with $100 \% \mathrm{~N}_{2}$ are initiated from different initial cell densities. Species ratios are shown under the cell densities.
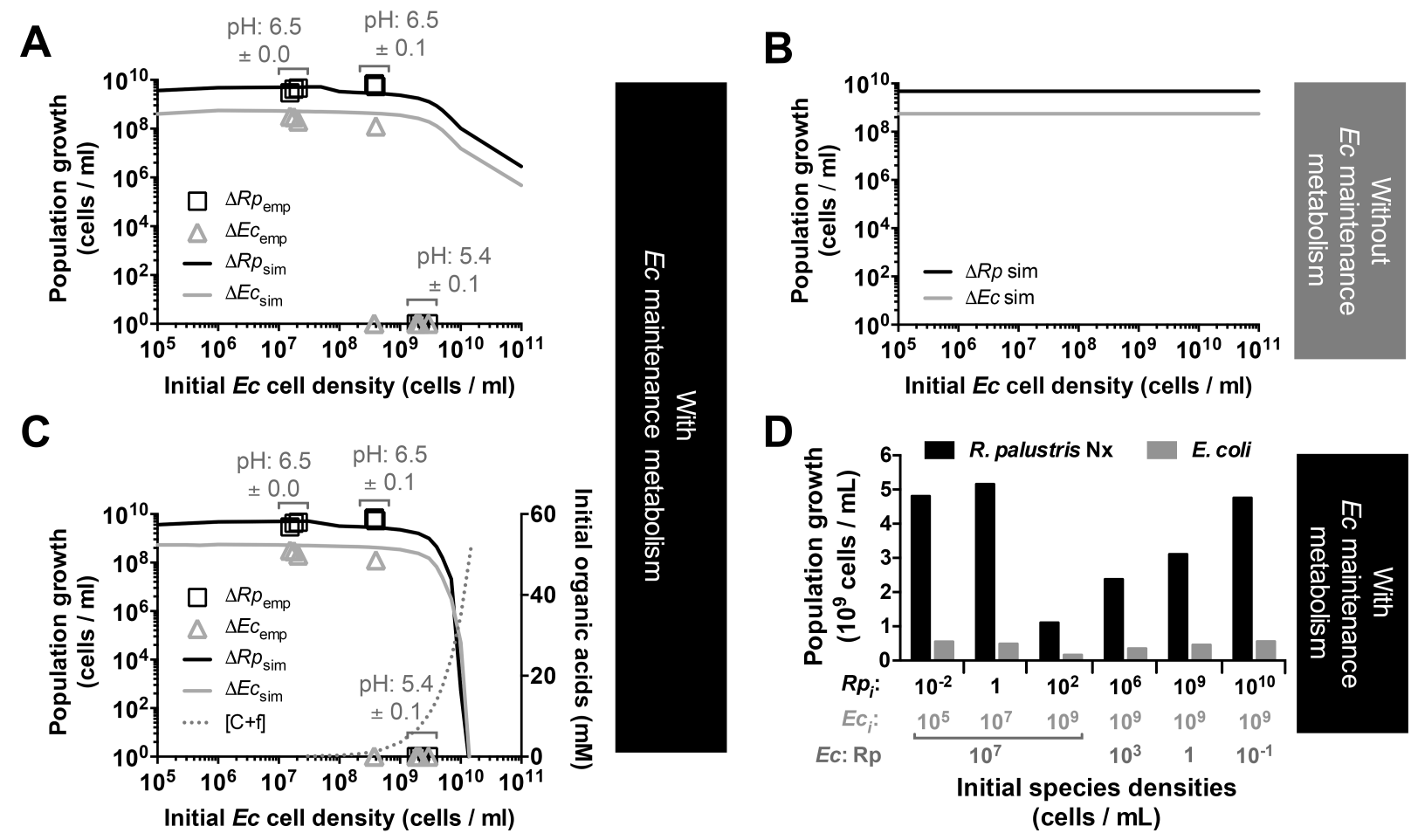


\title{
Supporting Information
}

\section{Growth-independent cross-feeding modifies boundaries for coexistence in a bacterial mutualism}

\author{
Alexandra L. McCully, Breah LaSarre, and James B. McKinlay \\ Department of Biology, Indiana University, Bloomington, IN
}

\section{Methods}

Mathematical modeling. A Monod model describing bi-directional cross-feeding in batch cultures, called SyFFoN_v2 (Syntrophy between Fermenter and Fixer of Nitrogen), was modified from our previous model (LaSarre et al., 2017) as follows: (i) a sigmoidal function, rather than a Monod function, was used to control the transition to growth-independent fermentation $\left(10 /\left(10+1.09^{\left(1000^{*} \mathrm{uEc}\right)}\right)\right)$; (ii) sigmoidal functions were used to transition from $\mathrm{NH}_{4}{ }^{+}$ excretion $\left(1-\left(40 /\left(40+1.29^{\mathrm{N}}\right)\right)\right)$ to $\mathrm{H}_{2}$ production $\left(40 /\left(40+1.29^{\mathrm{N}}\right)\right)$ by $R$. palustris as $\mathrm{N}_{2}$ becomes limiting; (iii) a sigmoidal function was used to simulate the inhibiting effects of accumulated organic acids on both growth and metabolism for both species $\left(b_{x} /\left(b_{x}+10^{(f+C)}\right)\right)$; (iv) a sigmoidal function was used to dampen growth-independent fermentation rates when consumable organic acids (lactate, succinate, and acetate) accumulate $\left(r_{x} *\left(100 /\left(100+6^{C}\right)\right)+r_{x \_}\right.$mono $)$and simulate the slow growth-independent fermentation observed in E. coli monocultures (LaSarre et al., 2017), compared to faster growth-independent fermentation in coculture; (v) R. palustris $\mathrm{H}_{2}$ production was coupled to consumable organic acid depletion, assuming that $0.5 \mathrm{CO}_{2}$ are produced per $\mathrm{H}_{2}$ (McKinlay et al., 2014); (vi) the R. palustris $\mathrm{Km}$ for $\mathrm{N}_{2}\left(\mathrm{~K}_{\mathrm{N}}\right)$ was given a value of $6 \mathrm{mM}$, based on the change in growth rate at limiting $\mathrm{N}_{2}$ concentrations in coculture; (vii) product formation parameters ( $\mathrm{R}$ and $\mathrm{r}$ ) were increased to more accurately simulate observed growth rates in coculture; (viii) the $E$. coli acid resistance parameter $\left(\mathrm{b}_{\mathrm{Ec}}\right)$ was increased relative to that for $R$. palustris ( $\mathrm{b}_{\mathrm{Rp}}$ ) based on terminal $\mathrm{pH}$ values observed in E. coli monocultures versus 
cocultures. The effects of these modifications can be visualized in Figure S4. Equations are listed below with default values in Supplementary Table 2. SyFFoN_v2 runs in R studio and is available for download at: https://github.com/McKinlab/Coculture-Mutualism.

Equations 1 and 2 were used to describe E. coli and R. palustris growth rates:

Eq. 1: E. coli growth rate; $\boldsymbol{\mu}_{\mathrm{Ec}}=\mu_{\mathrm{EcMAX}} \cdot\left[\mathrm{G} /\left(\mathrm{K}_{\mathrm{G}}+\mathrm{G}\right)\right] \cdot\left[\mathrm{A} /\left(\mathrm{K}_{\mathrm{A}}+\mathrm{A}\right)\right] \cdot\left[\mathrm{b}_{\mathrm{Ec}} /\left(\mathrm{b}_{\mathrm{Ec}}+10^{(\mathrm{f}+\mathrm{C})}\right)\right]$

Eq. 2: R. palustris growth rate; $\boldsymbol{\mu}_{\mathrm{Rp}}=\mu_{\mathrm{RpMAX}} \cdot\left[\mathrm{C} /\left(\mathrm{K}_{\mathrm{C}}+\mathrm{C}\right)\right] \cdot\left[\mathrm{N} /\left(\mathrm{K}_{\mathrm{N}}+\mathrm{N}\right)\right] \cdot\left[\mathrm{b}_{\mathrm{Rp}} /\left(\mathrm{b}_{\mathrm{Rp}}+10^{(\mathrm{f}+\mathrm{C})}\right)\right]$

Equations 3-12 were used to describe temporal changes in cell densities and extracellular compounds. Numerical constants in product excretion equations are used to account for molar stoichiometric conversions. Numerical constants used in sigmoidal functions are based on those values that resulted in simulations resembling empirical trends. All $\mathrm{R}$ and $\mathrm{r}$ parameters are expressed in terms of glucose consumed except for $\mathrm{R}_{\mathrm{A}}$, which is the amount of $\mathrm{NH}_{4}{ }^{+}$produced per R. palustris cell (Supplementary Table 2).

Eq. 3: Glucose; $\boldsymbol{d} \mathbf{G} / \boldsymbol{d} \mathbf{t}=-\mu_{\mathrm{Ec}} \cdot \mathrm{Ec} / \mathrm{Y}_{\mathrm{G}}-\mu_{\mathrm{Ec}} \cdot \mathrm{Ec} \cdot\left(\mathrm{R}_{\mathrm{c}}+\mathrm{R}_{\mathrm{f}}+\mathrm{R}_{\mathrm{e}}+\mathrm{R}_{\mathrm{CO} 2}\right)-$

$$
\begin{aligned}
& \mathrm{Ec} \cdot\left(\mathrm{G} /\left(\mathrm{K}_{\mathrm{G}}+\mathrm{G}\right)\right) \cdot\left(10 /\left(10+1.09^{(1000 \bullet \mu \mathrm{Ec})}\right)\right) \cdot\left(\mathrm{b}_{\mathrm{Ed}} /\left(\mathrm{b}_{\mathrm{Ec}}+10^{(\mathrm{f}+\mathrm{C})}\right)\right) \cdot\left(\left(100 /\left(100+6^{\mathrm{C}}\right)\right) \bullet\right. \\
& \left.\left(\mathrm{r}_{\mathrm{C}}+\mathrm{r}_{\mathrm{f}}+\mathrm{r}_{\mathrm{e}}+\mathrm{r}_{\mathrm{CO} 2}\right)+\mathrm{r}_{\mathrm{C}_{-} \text {mono }}+\mathrm{r}_{\mathrm{f}_{-} \text {mono }}+\mathrm{r}_{\mathrm{e}_{-} \text {mono }}+\mathrm{r}_{\mathrm{CO} 2 \_ \text {mono }}\right)
\end{aligned}
$$

Eq. 4: $\mathrm{N}_{2} ; \boldsymbol{d} \mathbf{N} / \boldsymbol{d} \mathbf{t}=-\mu_{R p} \cdot R p \cdot 0.5 \cdot R_{A} \cdot\left(1-\left(40 /\left(40+1.29^{N}\right)\right)-\mu_{R p} \cdot R p / Y_{N}\right.$

Eq. 5: Consumable organic acids; $\boldsymbol{d} \mathbf{C} / \boldsymbol{d} \mathbf{t}=\mathrm{Ec} \cdot 2 \cdot\left(\mu_{\mathrm{Ec}} \cdot \mathrm{R}_{\mathrm{c}}+\right.$

$$
\begin{aligned}
& \left.\left(\mathrm{G} /\left(\mathrm{K}_{\mathrm{G}}+\mathrm{G}\right)\right) \cdot\left(10 /\left(10+1.09^{(1000 \cdot \mu \mathrm{Ec})}\right)\right) \cdot\left(\mathrm{b}_{\mathrm{Ec}} /\left(\mathrm{b}_{\mathrm{Ec}}+10^{(\mathrm{f}+\mathrm{C})}\right)\right) \cdot\left(\mathrm{r}_{\mathrm{C}} \cdot\left(100 /\left(100+6^{\mathrm{C}}\right)\right)+\mathrm{r}_{\mathrm{C}_{-} m o n o}\right)\right)- \\
& \left(\mu_{\mathrm{Rp}} \cdot \mathrm{Rp} / \mathrm{Y}_{\mathrm{C}}\right)-0.25 \cdot \mathrm{Rp} \cdot\left(\mu_{\mathrm{Rp}} \cdot \mathrm{Rh}_{\mathrm{Rp}}+\mathrm{r}_{\mathrm{Hp}} \cdot\left(\mathrm{C} /\left(\mathrm{K}_{\mathrm{C}}+\mathrm{C}\right)\right) \cdot\left(40 /\left(40+1.29^{\mathrm{N}}\right)\right) \cdot\left(\mathrm{b}_{\mathrm{Rp}} /\left(\mathrm{b}_{\mathrm{Rp}}+10^{(\mathrm{f}+\mathrm{C})}\right)\right)\right)
\end{aligned}
$$

Eq. 6: Formate; $\boldsymbol{d} \mathbf{f} / \boldsymbol{d} \mathbf{t}=\operatorname{Ec} \bullet 6 \bullet\left(\mu_{\mathrm{Ec}} \bullet \mathrm{R}_{\mathrm{f}}+\left(\mathrm{G} /\left(\mathrm{K}_{\mathrm{G}}+\mathrm{G}\right)\right) \bullet\left(10 /\left(10+1.09^{(1000 \bullet \mu \mathrm{Ec})}\right)\right) \bullet\right.$

$$
\left.\left(b_{E c} /\left(b_{E c}+10^{(f+C)}\right)\right) \cdot\left(r_{f} \bullet\left(100 /\left(100+6^{C}\right)\right)+r_{f_{-} m o n o}\right)\right)
$$


Eq. 7: $\mathrm{NH}_{4}^{+} ; \boldsymbol{d} \mathbf{A} / \boldsymbol{d} \mathbf{t}=\mathrm{Rp} \bullet \mu_{\mathrm{Rp}} \bullet \mathrm{R}_{\mathrm{A}} \bullet\left(1-\left(40 /\left(40+1.29^{\mathrm{N}}\right)\right)\right)-\mu_{\mathrm{Ec}} \bullet \mathrm{Ec} / \mathrm{Y}_{\mathrm{A}}$

Eq. 8: E. coli; $\boldsymbol{d} \mathbf{E c} / \mathbf{d t}=\mu_{\mathrm{Ec}} \cdot \mathrm{Ec}$

Eq. 9: $R$. palustris; $\boldsymbol{d} \mathbf{R p} / \boldsymbol{d} \mathbf{t}=\mu_{\mathrm{Rp}} \cdot \mathrm{Rp}$

Eq. 10: Ethanol; $\boldsymbol{d e} / \boldsymbol{d} \mathbf{t}=\mathrm{Ec} \cdot 3 \cdot\left(\mu_{\mathrm{Ec}} \cdot \mathrm{R}_{\mathrm{e}}+\left(\mathrm{G} /\left(\mathrm{K}_{\mathrm{G}}+\mathrm{G}\right)\right) \cdot\left(10 /\left(10+1.09^{(1000 \cdot \mu \mathrm{Ec})}\right)\right)\right.$

$$
\text { - } \left.\left(\mathrm{b}_{\mathrm{Ec}} /\left(\mathrm{b}_{\mathrm{Ec}}+10^{(\mathrm{f}+\mathrm{C})}\right)\right) \cdot\left(\mathrm{r}_{\mathrm{e}} \cdot\left(100 /\left(100+6^{\mathrm{C}}\right)\right)+\mathrm{r}_{\_} \text {mono }\right)\right)
$$

Eq. 11: $\mathrm{CO}_{2} ; \boldsymbol{d} \mathbf{C O} 2 / \boldsymbol{d} \mathbf{t}=\mathrm{Ec} \bullet 6 \bullet\left(\mu_{\mathrm{Ec}} \bullet \mathrm{R}_{\mathrm{CO} 2}+\left(\mathrm{G} /\left(\mathrm{K}_{\mathrm{G}}+\mathrm{G}\right)\right) \bullet\left(10 /\left(10+1.09^{(1000 \bullet \mu \mathrm{Ec})}\right)\right) \bullet\right.$

$$
\begin{gathered}
\left.\left(\mathrm{b}_{\mathrm{Ec}} /\left(\mathrm{b}_{\mathrm{Ec}}+10^{(\mathrm{f}+\mathrm{C})}\right)\right) \cdot\left(\mathrm{r}_{\mathrm{co} 2} \bullet\left(100 /\left(100+6^{\mathrm{C}}\right)\right)+\mathrm{r}_{\mathrm{co} 2} \mathrm{mono}\right)\right)+\mathrm{Rp} \bullet 0.5 \cdot\left(\mu_{\mathrm{Rp}} \bullet \mathrm{Rh}_{\mathrm{Rp}}+\right. \\
\left.\mathrm{r}_{\mathrm{Hp}} \bullet\left(\mathrm{C} /\left(\mathrm{K}_{\mathrm{C}}+\mathrm{C}\right)\right) \cdot\left(40 /\left(40+1.29^{\mathrm{N}}\right)\right) \cdot\left(\mathrm{b}_{\mathrm{Rp}} /\left(\mathrm{b}_{\mathrm{Rp}}+10^{(\mathrm{f}+\mathrm{C})}\right)\right)\right)
\end{gathered}
$$

Eq. 12: $\mathrm{H}_{2} ; \boldsymbol{d} \mathbf{H} / \boldsymbol{d} \mathbf{t}=\mathrm{Rp} \bullet\left(\mu_{\mathrm{R} p} \bullet \mathrm{R}_{\mathrm{HRp}}+\mathrm{r}_{\mathrm{Hp}} \bullet\left(\mathrm{C} /\left(\mathrm{K}_{\mathrm{C}}+\mathrm{C}\right)\right) \bullet\left(40 /\left(40+1.29^{\mathrm{N}}\right)\right) \bullet\right.$

$$
\begin{aligned}
& \left.\left(b_{\mathrm{Rp}} /\left(\mathrm{b}_{\mathrm{Rp}}+10^{(\mathrm{f}+\mathrm{C})}\right)\right)\right)+\mathrm{Ec} \cdot\left(\mu_{\mathrm{Ec}} \cdot \mathrm{R}_{\mathrm{HEc}}+\left(\mathrm{G} /\left(\mathrm{K}_{\mathrm{G}}+\mathrm{G}\right)\right) \cdot\left(10 /\left(10+1.09^{(1000 \cdot \mu \mathrm{Ec})}\right)\right) \cdot\right. \\
& \left.\left(\mathrm{b}_{\mathrm{Ec}} /\left(\mathrm{b}_{\mathrm{Ec}}+10^{(\mathrm{f}+\mathrm{C})}\right)\right) \cdot\left(\mathrm{r}_{\mathrm{H}} \cdot\left(100 /\left(100+6^{\mathrm{C}}\right)\right)+\mathrm{r}_{\mathrm{H}} \text { mono }\right)\right)
\end{aligned}
$$

Where,

$\mu$ is the specific growth rate of the indicated species $\left(\mathrm{h}^{-1}\right)$.

$\mu_{\text {MAX }}$ is the maximum specific growth rate of the indicated species $\left(\mathrm{h}^{-1}\right)$.

$\mathrm{G}, \mathrm{A}, \mathrm{C}, \mathrm{N}, \mathrm{f}, \mathrm{e}, \mathrm{H}$ and $\mathrm{CO} 2$ are the concentrations $(\mathrm{mM})$ of glucose, $\mathrm{NH}_{4}{ }^{+}$, consumable organic acids, $\mathrm{N}_{2}$, formate, ethanol, $\mathrm{H}_{2}$, and $\mathrm{CO}_{2}$, respectively. All gasses are assumed to be fully dissolved. Consumable organic acids are those that $R$. palustris can consume, namely, lactate (3 carbons), acetate ( 2 carbons), and succinate ( 4 carbons). All consumable organic acids were simulated to have three carbons for convenience. Only net accumulation of formate, ethanol, $\mathrm{CO}_{2}$ and $\mathrm{H}_{2}$ are described in accordance with observed trends.

$\mathrm{K}$ is the half saturation constant for the indicated substrate $(\mathrm{mM})$.

Ec and Rp are the cell densities (cells $/ \mathrm{ml}$ ) of E. coli and R. palustris, respectively. 
$\mathrm{b}$ is the ability of a species to resist the inhibiting effects of acid (mM). Default values were chosen based on levels of formate and other organic acids observed to inhibit growth and metabolism in cocultures and E. coli monocultures.

$\mathrm{Y}$ is the E. coli or R. palustris cell yield from the indicated substrate (cells / $\mu$ mol glucose). Y values were determined in MDC with the indicated substrate as the limiting nutrient.

$\mathrm{R}$ is the fraction of glucose converted into the indicated compound per $E$. coli cell during growth ( $\mu \mathrm{mol}$ of glucose / E. coli cell), except for $\mathrm{R}_{\mathrm{A}}$. Values were adjusted to accurately simulate product yields measured in cocultures and in MDC with and without added $\mathrm{NH}_{4} \mathrm{Cl}$. $\mathrm{R}_{\mathrm{A}}$ is the ratio of $\mathrm{NH}_{4}{ }^{+}$produced per $R$. palustris cell during growth $(\mu \mathrm{mol} / R$. palustris cell). The default value was based on that which accurately simulated empirical trends. $\mathrm{r}$ is the growth-independent rate of glucose converted into the indicated compound ( $\mu \mathrm{mol} / \mathrm{cell}$ / h). Default values are based on those which accurately simulated empirical trends in coculture. $\mathrm{r}_{-}$mono is the growth-independent rate of glucose converted into the indicated compound by E. coli when consumable organic acids accumulate. Default values are based on linear regression of products accumulated over time in nitrogen-free cell suspensions of $E$. coli (LaSarre et al., 2017). 

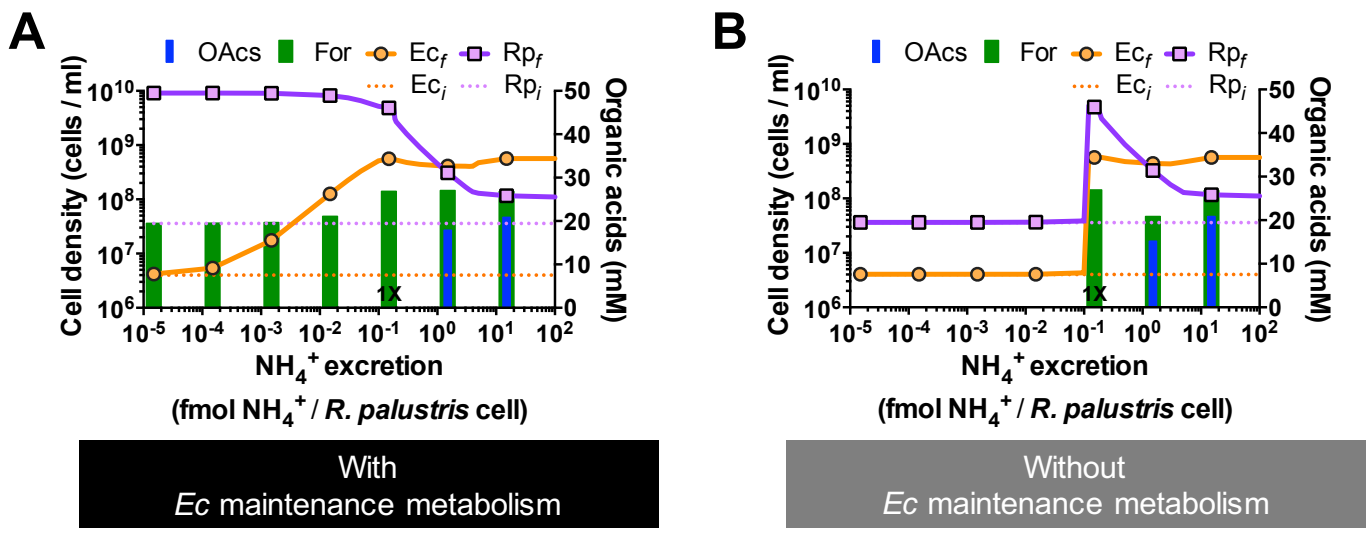

Figure S1. SyFFoN_v2 predicts that coexistence at low $\mathrm{NH}_{4}{ }^{+}$cross-feeding levels requires E. coli maintenance metabolism. Simulated effect of the $R$. palustris $\mathrm{NH}_{4}{ }^{+}$excretion level on growth and organic acid accumulation in $100 \% \mathrm{~N}_{2}$-supplied cocultures in the presence (A) or absence (B) of E. coli maintenance metabolism. $1 \mathrm{X}$ is the default $\mathrm{NH}_{4}{ }^{+}$excretion level $(0.15$ fmol $\mathrm{NH}_{4}^{+}$/ cell) and is thought to represent that excreted by R. palustris $\mathrm{Nx}$ based on model approximation of empirical trends. OAcs, consumable organic acids (lactate, acetate, and succinate); For, formate; $E c_{i}$ and $R p_{i}$, initial $E$. coli $(E c)$ and $R$. palustris $(R p)$ cell densities; $\mathrm{Ec}_{f}$ and $\mathrm{Rp}_{f}$, final E. coli and $R$. palustris cell densities. (A) Trends from SyFFoN_v2 are consistent with trends from a previous version of the model (LaSarre et al., 2017).

A

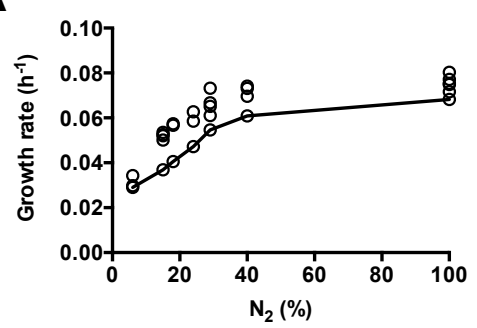

B

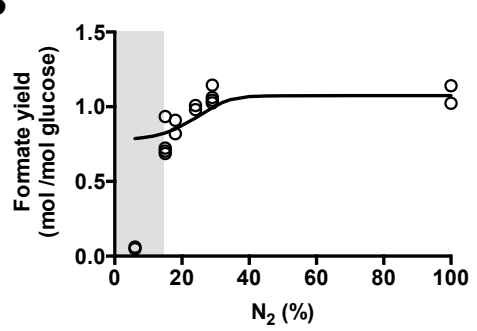

C

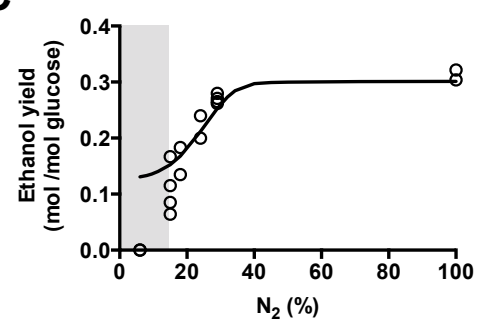

Figure S2. SyFFoN_v2 predictions of growth rates (A), formate yields (B), and ethanol yields $(C)$ at various $\mathbf{N}_{2}$ concentrations. Circles indicate empirical data from shaken cocultures. Lines indicate model predictions. Shaded regions indicate low $\mathrm{N}_{2}$ concentrations where empirical trends do not match model predictions. 


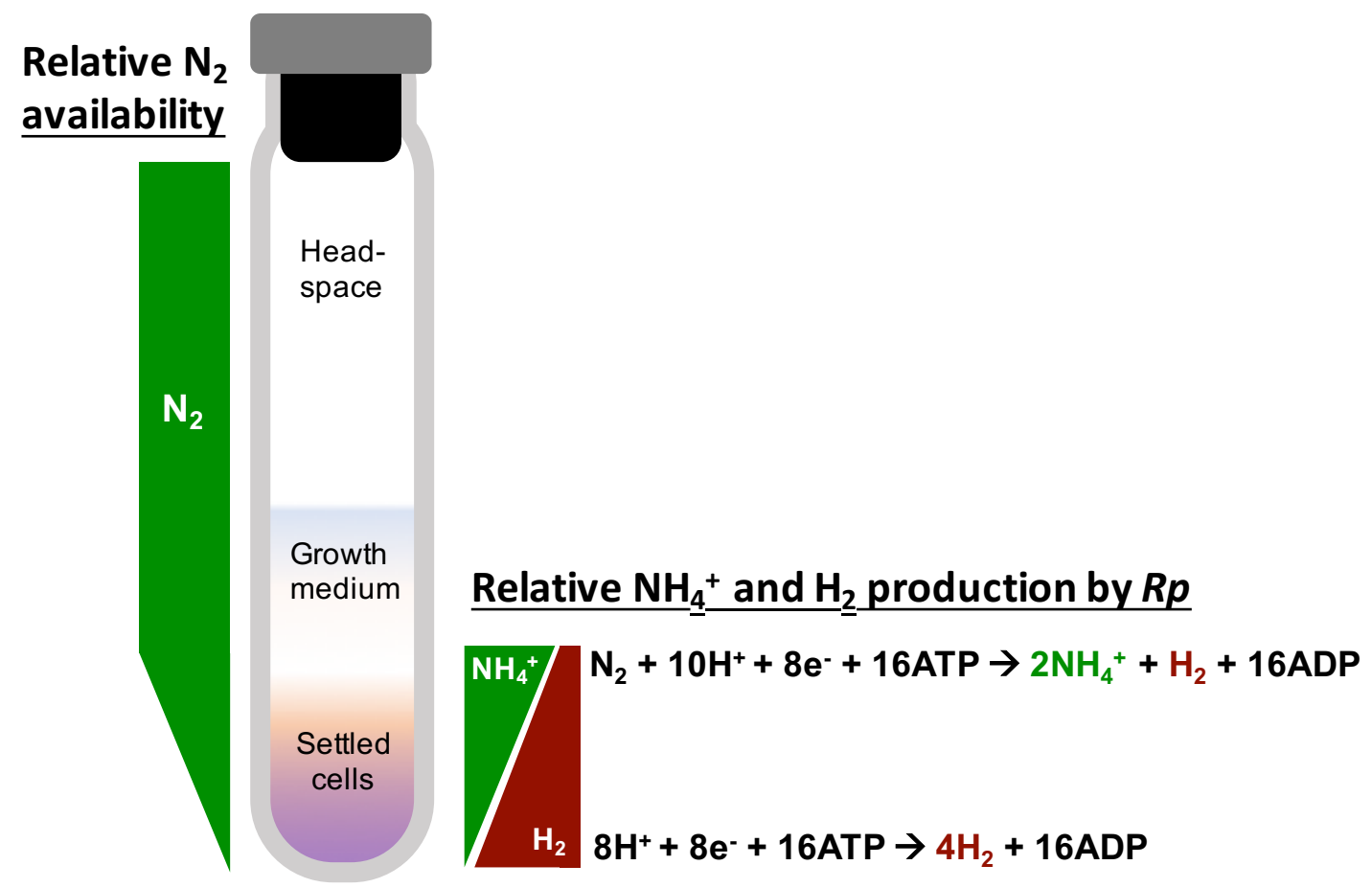

Figure S3. Cell settling in static cocultures is assumed to lead to zone of $\mathrm{N}_{2}$ limitation that favors $\mathrm{H}_{2}$ production over $\mathrm{NH}_{4}^{+}$production. With saturating $\mathrm{N}_{2}$, nitrogenase produces 2 moles of $\mathrm{NH}_{4}^{+}$and one mole of $\mathrm{H}_{2}$ for every mole of $\mathrm{N}_{2}$ fixed (top equation). When $\mathrm{N}_{2}$ is absent, nitrogenase only produces $\mathrm{H}_{2}$ (bottom equation). Under sub-saturating $\mathrm{N}_{2}$ conditions, the amounts of $\mathrm{NH}_{4}^{+}$and $\mathrm{H}_{2}$ produced would be somewhere between the two equations. 
A

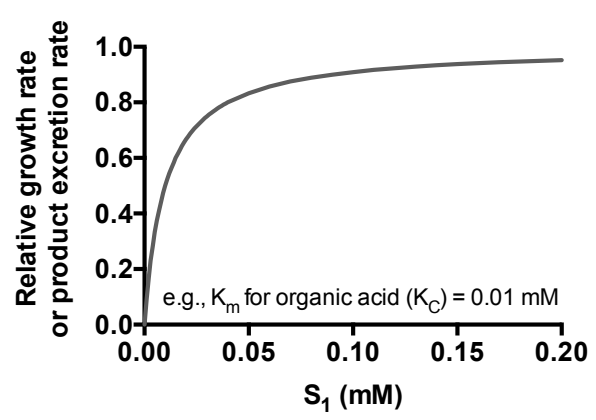

B

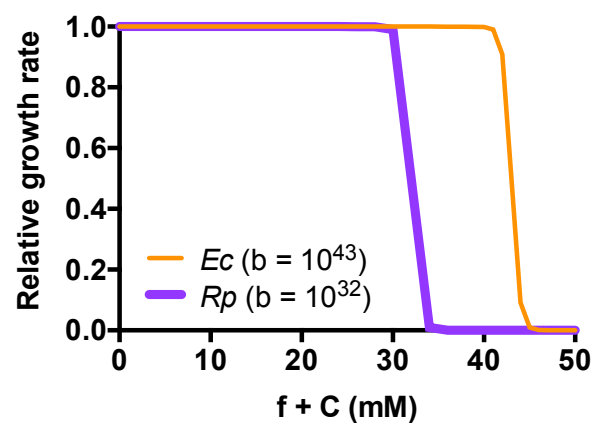

C

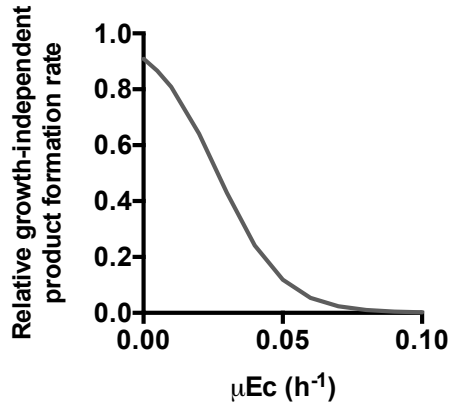

D

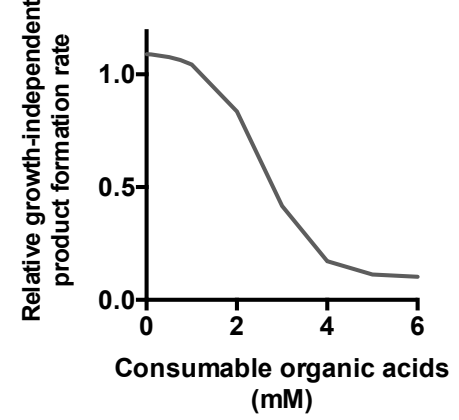

E

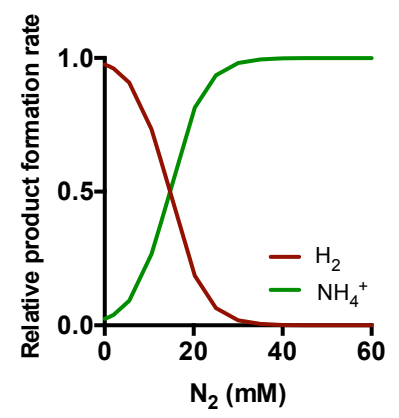

$\mu_{\mathrm{X}}=\mu_{\mathrm{X}} \operatorname{Max} \cdot \ldots \cdot \mathbf{S} 1 /\left(\mathrm{K}_{\mathbf{S} 1}+\mathbf{S} 1\right)$

Where,

$\mu_{X}$ is the growth rate of species $X\left(h^{-1}\right)$

$\mu_{X}$ Max is the maximum growth rate of speceis $X\left(h^{-1}\right)$

$S_{\#}$ is the concentration of a given substrate $(\mathrm{mM})$

$\mathrm{K}_{\mathrm{SH}}$ is the $\mathrm{Km}$ value for a given substrate $(\mathrm{mM})$

$\mu_{X}=\mu_{x} \operatorname{Max} \cdot \ldots \cdot b_{x} /\left(b_{x}+10^{(f+C)}\right)$

Where,

$\mu_{X}$ is the growth rate of species $X\left(h^{-1}\right)$

$\mu_{X}$ Max is the maximum growth rate of speceis $X\left(h^{-}\right.$ 1)

$b_{x}$ is an arbitrary value used to indicate the ability of species $\mathrm{X}$ to resist inhibition by acid

$f$ is the concentration of formate $(\mathrm{mM})$

$\mathrm{C}$ is the concentration of consumable organic acids (acetate, lactate, and succinate; $\mathrm{mM}$ )

$d P / d t=r_{P} \cdot \ldots \cdot 10 /\left(10+1.09^{(1000 \bullet \mu E c)}\right)$

Where,

$d P / d t$ is the change in product concentration per unit time $(\mathrm{mM} / \mathrm{h})$

$r_{p}$ is the maximum growth-independent rate of product formation in coculture

$\mu \mathrm{Ec}$ is the growth rate of $E$. coli $\left(\mathrm{h}^{-1}\right)$

$d P / d t=r_{P} \cdot \ldots \cdot\left(100 /\left(100+6^{C}\right)+r_{P_{-} \text {mono }}\right)$

Where,

$d P / d t$ is the change in product concentration per unit time $(\mathrm{mM} / \mathrm{h})$

$r_{P}$ is the maximum growth-independent rate of product formation in coculture

$r_{P}$ is the maximum growth-independent rate of product formation in coculture

$\mathrm{r}_{\mathrm{P}_{-} \text {mono }}$ is the maximum growth-independent rate of product formation in $E$. colicell suspensions

$d A / d t=R p \cdot \mu R p \cdot R A \cdot \ldots \cdot 1-\left(40 /\left(40+1.29^{N}\right)\right)$

$d H / d t=r H p \cdot \ldots \cdot 40 /\left(40+1.29^{N}\right)$

Where,

$d P / d t$ is the change in product concentration per unit time $(\mathrm{mM} / \mathrm{h})$

$r_{p}$ is the maximum growth-independent rate of product formation in coculture

$r_{p}$ is the maximum growth-independent rate of product formation in coculture

$\mathrm{r}_{\mathrm{P}_{\text {_mono }}}$ is the maximum growth-independent rate of product formation in $E$. coli cell suspensions 
Figure S4. The effect of SyFFoN_v2 functions on growth rate and product formation rates. (A) Growth rate approaches zero as substrate supply is exhausted according to a Monod model (whole-cell Michaelis-Menten kinetics). The function, $\mathrm{S} 1 /\left(\mathrm{K}_{\mathrm{S} 1}+\mathrm{S} 1\right)$, is used in SyFFoN_v2 equations 1 and 2 to control growth rates in response to substrate concentration. The function was also used in equations $3,5,6,10,11$, and 12 to control growth-independent product excretion rates in response to substrate concentration. The function was not applied to growthdependent product excretion rates since these are already dependent on growth rate which in turn is dependent on substrate concentration. Km values were taken from the literature or assumed as indicated in Supplementary Table 2. The Km value for $\mathrm{N}_{2}$ was determined experimentally from $R$. palustris exponential growth rates at different $\mathrm{N}_{2}$ concentrations (Figure $\mathrm{S} 5$ ).

(B) Growth rate declines sharply at a threshold organic acid concentration according to the sigmoidal function, $b_{X} /\left(b_{X}+\mathbf{1 0}^{(f+C)}\right)$. The curve was modeled to resemble that of an acid titration curve in buffer. The function is used in equations 1 and 2 to control growth rate in response to acid accumulation. The function was also used in equations 3, 5, 6, 10, 11, and 12 to control growth-independent product excretion rates in response to acid accumulation. The function was not applied to growth-dependent product excretion rates since these are already dependent on growth rate which in turn is dependent on organic acid concentration. Values for ' $b$ ' were determined by manually varying values until simulated growth inhibition occurred at organic acid levels resembling those observed in cocultures and $E$. coli monocultures with excess glucose, such that growth halted due to acid accumulation.

(C) E. coli growth-independent fermentation rates $(\mu \mathrm{mol} /$ cell $/ \mathrm{h})$ increase as the $E$. coli growth rate decreases according to the sigmoidal function, $\mathbf{1 0} /(\mathbf{1 0}+\mathbf{1 . 0 9}(\mathbf{1 0 0 0} \mu \mathrm{Ec}))$. The function is used in equations $3,5,6,10,11$, and 12 to transition to growth-independent product formation rates when $E$. coli growth slows. Product formation rates associated with maintenance metabolism (r) were modeled to increase as $E$. coli growth slows rather than being kept constant since product formation rates observed in non-growing $E$. coli cell suspensions with glucose could not explain the rate of $R$. palustris growth and formate accumulation in cocultures. Consumption of organic acids by $R$. palustris likely increases these growth-independent fermentation rates by removing inhibitory effects of end-products. The values of ' 10 ' and ' 1.09 ' were arrived at after manually trying several arbitrary values to control the total time for coculture growth (see Figure S6A).

(D) E. coli growth-dependent fermentation rates ( $\mu \mathrm{mol} / \mathrm{cell} / \mathrm{h})$ decrease to a rate observed in non-growing $E$. coli cell suspensions as consumable organic acid concentrations increase according to the sigmoidal function, $\left(\mathbf{1 0 0} /\left(\mathbf{1 0 0}+\mathbf{6}^{\mathrm{C}}\right)\right)+\mathrm{r}_{\mathbf{P}}$ mono $)$. The function is used in equations $3,5,6,10,11$, and 12 to transition to growth-independent product formation rates observed in $E$. coli cell suspensions when consumable organic acids accumulate. This function is necessary to ensure that the model does not use the high growth-independent fermentation rates observed in coculture when consumable organic acids accumulate (e.g., when the $\mathrm{NH}_{4}{ }^{+}$availability is low and the $E$. coli density is high, or in nitrogen-starved $E$. coli cell suspensions). The function uses $\mathrm{C}$ (consumable organic acids) instead of $(\mathrm{C}+\mathrm{f})$ (consumable organic acids and formate), to avoid incorrectly halting formate production in cocultures even when $\mathrm{C}$ is fully consumed. The values of ' 100 ' and ' 6 ' were arrived at after manually trying several arbitrary values to control the levels of organic acid accumulation similar to what is observed in nitrogen-starved E. coli cell suspensions (see Figure S6B and C). 
(E) As $\mathrm{N}_{2}$ availability increases, the $R$. palustris nitrogenase activity shifts from producing only $\mathrm{H}_{2}$ to a mixture of $\mathrm{H}_{2}$ and $\mathrm{NH}_{4}{ }^{+}$according to:

$$
\text { No } \mathrm{N}_{2}: \quad 8 \mathrm{H}^{+}+8 \mathrm{e}^{-}+16 \mathrm{ATP} \rightarrow \quad 4 \mathrm{H}_{2}+16 \mathrm{ADP}
$$

Saturating $\mathrm{N}_{2}: \quad \mathrm{N}_{2}+10 \mathrm{H}^{+}+8 \mathrm{e}^{-}+16 \mathrm{ATP} \rightarrow 2 \mathrm{NH}_{4}^{+}+\mathrm{H}_{2}+16 \mathrm{ADP}$

In SyFFoN_v2 this shift is controlled by two functions. One function, $\mathbf{1 - ( 4 0 / ( 4 0 + 1 . 2 9 ^ { \mathrm { N } } ) )}$ (green) is used in equation 4 to increase $\mathrm{NH}_{4}{ }^{+}$production with increasing $\mathrm{N}_{2}$ concentration. The other function, $\mathbf{4 0} /\left(\mathbf{4 0}+\mathbf{1 . 2 9}^{\mathrm{N}}\right.$ ) (red) is used in equation 12 to decrease $\mathrm{H}_{2}$ production with increasing $\mathrm{N}_{2}$ concentration. The values of ' 40 ' and ' 1.29 ' were arrived at after manually trying several arbitrary values to control the shape of the curves and give final product yields similar to those observed in Figure 3 and Figure S2 (see also Figure S6D).

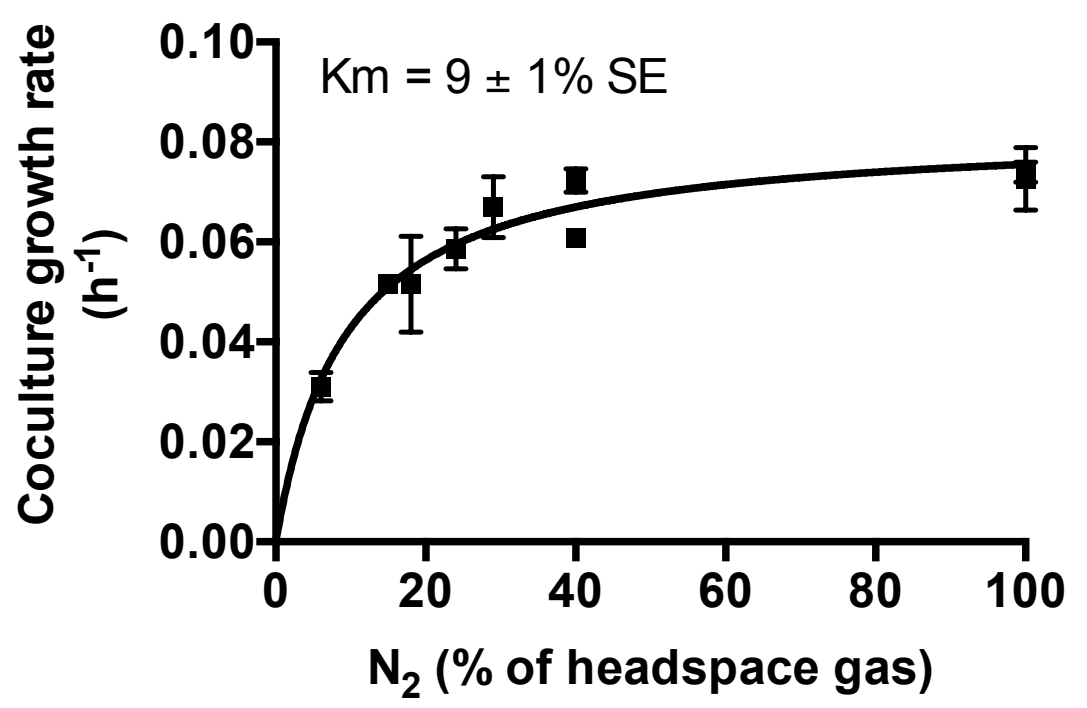

Figure S5. Determination of $R$. palustris whole cell $\mathrm{Km}$ value for $\mathbf{N}_{2}$ in coculture. A Michaelis-Menten curve was fit to coculture growth rate data determined at various $\mathrm{N}_{2}$ concentrations using Graphpad Prism v.6.0h. Symbol error bars are SD. 
A

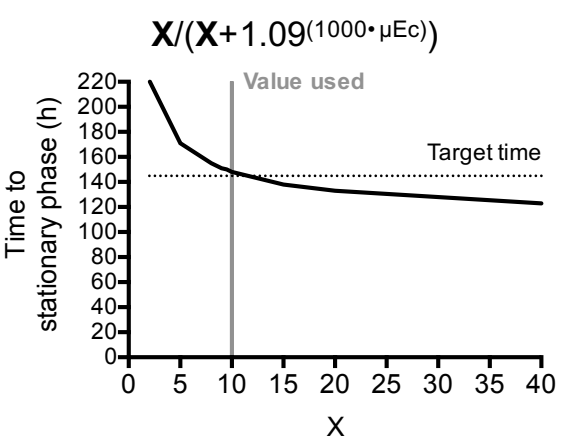

B

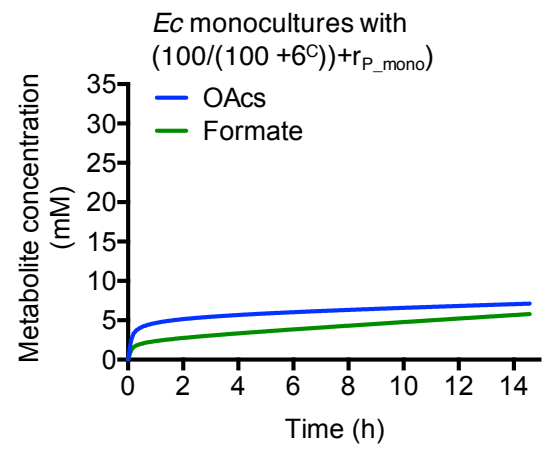

C

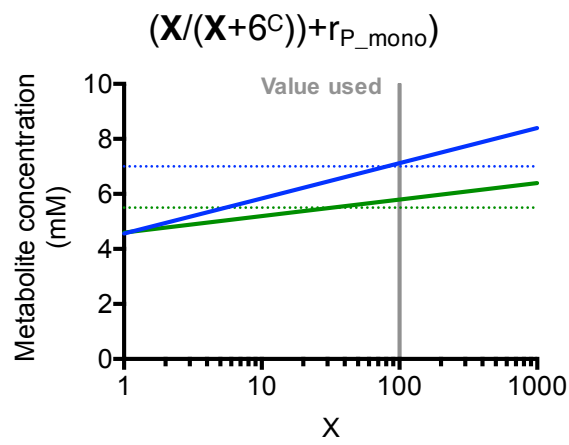

D

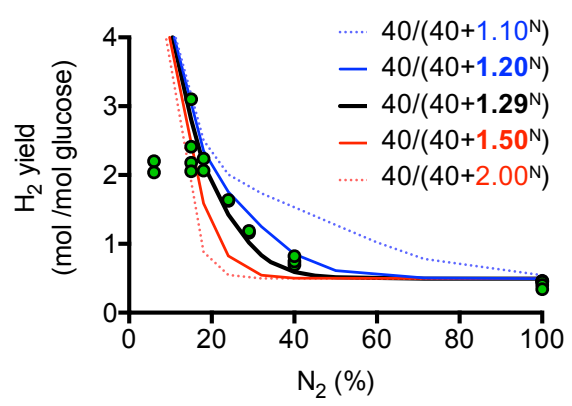

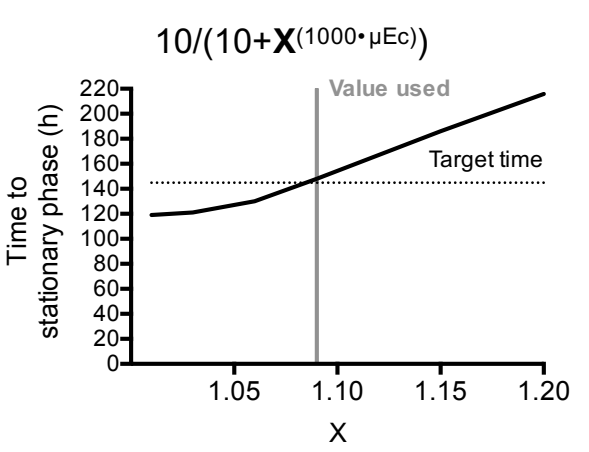
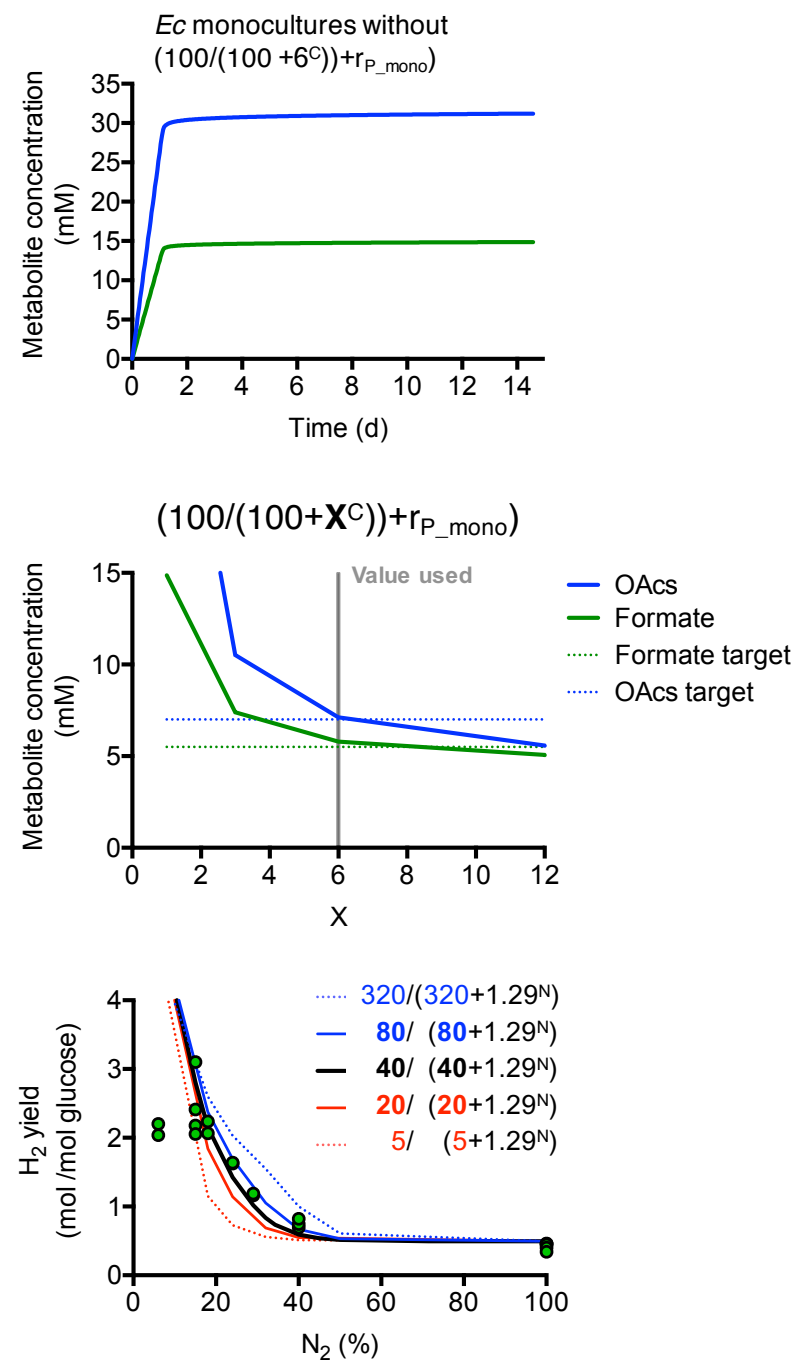

Figure S6. Effect of arbitrarily chosen function values on simulated trends.

(A) Altering the arbitrary values of 10 (left panel) and 1.09 (right panel) in the function $\mathbf{1 0} /\left(\mathbf{1 0}+\mathbf{1 . 0 9}{ }^{(1000 \cdot \mu \mathrm{Ec})}\right)$ affects the simulated time required for cocultures to reach stationary phase (i.e., when the optical density is observed to plateau). The example shown is for simulated coculture times with $18 \% \mathrm{~N}_{2}$ for which experimental cocultures were observed to reach stationary phase in approximately $145 \mathrm{~h}$ (dotted line). 


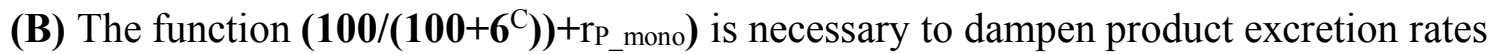
associated with E. coli maintenance metabolism (r) when consumable organic acids accumulate, such as in simulations of nitrogen-starved $E$. coli cell suspensions (left panel; compare with trends in Figure S9) or when E. coli cell densities in coculture are high but $\mathrm{NH}_{4}{ }^{+}$availability is low. Without this function organic acids would accumulate in simulations of nitrogen-starved $E$. coli cell suspensions at an unrealistically high rate (right panel).

(C) Altering the arbitrary values of 100 (left panel) and 6 (right panel) in the function $\left(\mathbf{1 0 0 / ( 1 0 0 + 6 ^ { C } ) )}+\mathrm{r}_{\text {P_mono }}\right)$ affects the levels of metabolite accumulation in nitrogen-starved $E$. coli cell suspensions by $14 \mathrm{~d}$. Target concentrations of $7 \mathrm{mM}$ consumable organic acids and $5.5 \mathrm{mM}$ formate were chosen based on approximate levels observed in experimental nitrogen-starved $E$. coli cell suspensions at $14 \mathrm{~d}$ (Figure S9).

(D) Altering the arbitrary values of 1.29 (left panel) and 40 (right panel) in the function $\mathbf{4 0} /\left(\mathbf{4 0}+\mathbf{1 . 2 9}{ }^{\mathrm{N}}\right)$ affects product yields over different $\mathrm{N}_{2}$ concentrations. The example shown overlays simulated $\mathrm{H}_{2}$ yields (red and blue lines) on Figure 3A when different arbitrary values are used, with green dots representing experimentally determined $\mathrm{H}_{2}$ yields and the black line representing simulated values when the values 40 and 1.29 were used in the function. Use of different arbitrary values similarly affected other simulated product yields and growth yields by shifting trends for away from observed values. 
A

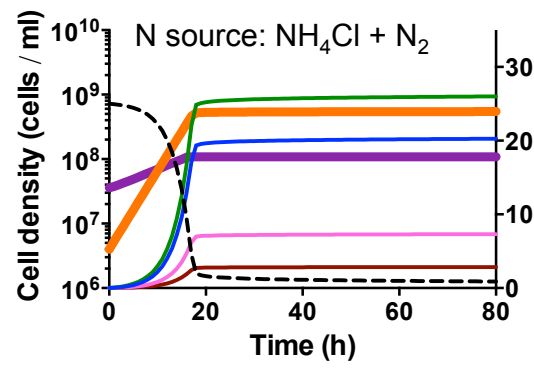

B

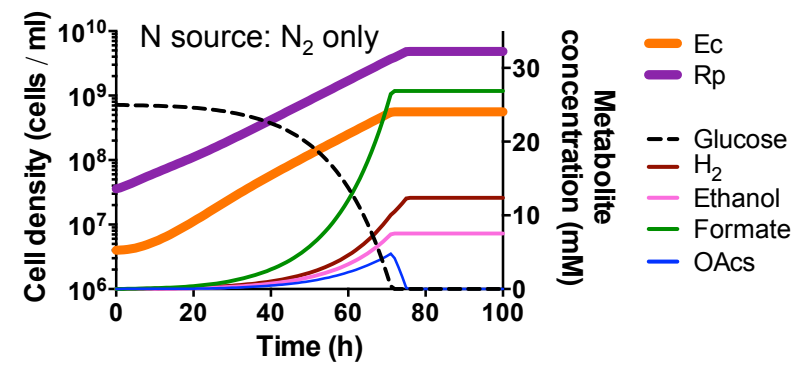

Figure S7. SyFFoN_v2 simulations of batch cocultures with and without externally added $\mathbf{N H}_{4}{ }^{+}$. (A, B) Simulated growth and metabolic profiles of cocultures supplied with $\mathrm{NH}_{4}^{+}$ (parameter $\mathrm{A}=15 \mathrm{mM})(\mathbf{A})$ or $100 \% \mathrm{~N}_{2}$ alone (B). Ec, E. coli; Rp, R. palustris; OAcs, consumable organic acids (lactate, acetate, and succinate). Trends from SyFFoN_v2 are consistent with trends from a previous version of the model (LaSarre et al., 2017).
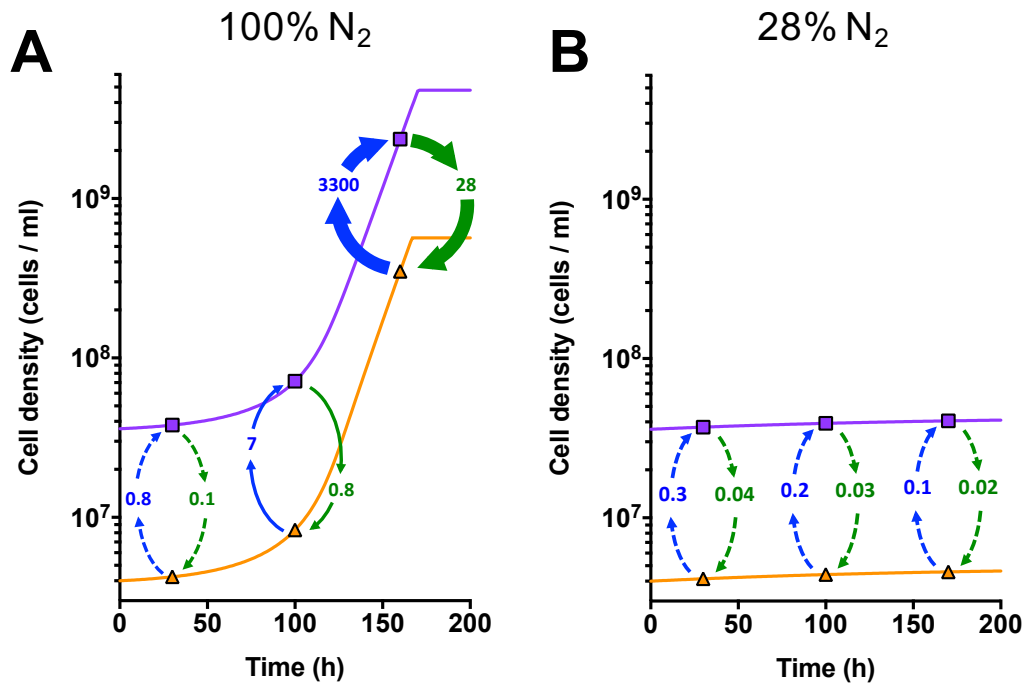

Without

\section{Ec maintenance metabolism}

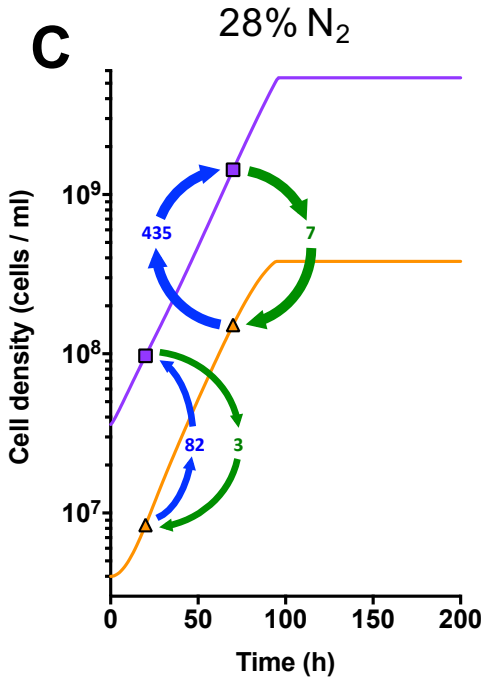

With

Ec maintenance

metabolism

Figure S8. $E$. coli maintenance metabolism is predicted to permit coculture growth at low $\mathbf{N}_{2}$ concentrations by circumventing diminishing returns. Simulated exchange of $\mathrm{NH}_{4}{ }^{+}$ (green) and consumable organic acids (blue) during growth of E. coli (orange lines, triangles) and $R$. palustris (purple lines, squares) populations when maintenance metabolism is omitted (A, B) or included (C). Cross-fed $\mathrm{NH}_{4}{ }^{+}$and organic acid values for the indicated time points (symbols) are the sum of those free in the medium plus those assimilated in the exchange $(\mu \mathrm{M})$. 
A

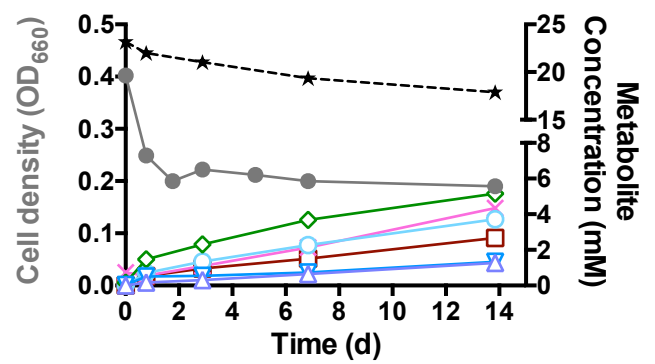

B
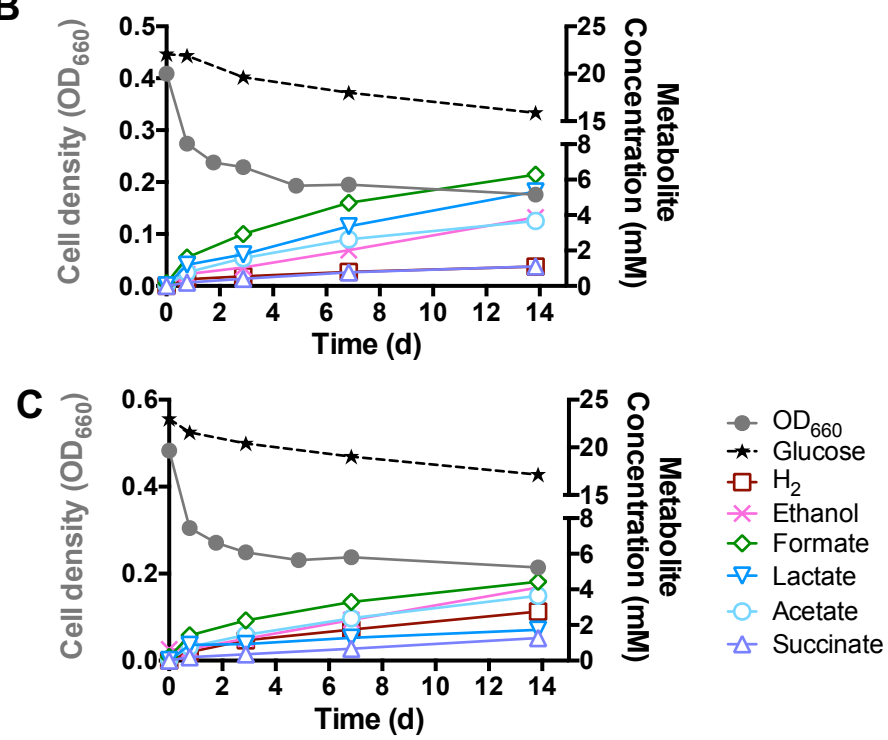

D

\begin{tabular}{lccc}
\hline & \multicolumn{2}{c}{$\begin{array}{c}\text { Specific formation rate } \\
\text { (attomol glucose } / \text { CFU / } \text { ) }\end{array}$} & $\begin{array}{c}\text { Fold } \\
\text { change }\end{array}$ \\
\cline { 2 - 3 } $0-1$ days & $1-7$ days & \\
\hline $\mathrm{H}_{2}$ & $23 \pm 5$ & $7 \pm 3$ & -3.3 \\
Ethanol & $6 \pm 5$ & $5 \pm 0$ & -1.2 \\
Formate & $11 \pm 1$ & $4 \pm 1$ & -2.8 \\
Lactate & $21 \pm 8$ & $2 \pm 0$ & -10.5 \\
Acetate & $12 \pm 1$ & $5 \pm 1$ & -2.4 \\
Succinate & $6 \pm 0$ & $3 \pm 1$ & -2.0 \\
\hline
\end{tabular}

Figure S9. Estimation of $\boldsymbol{E}$. coli fermentation rates associated with maintenance metabolism in cell suspensions lacking nitrogen. (A-C) Growth and metabolic trends in nitrogen-starved E. coli cell suspensions. Each panel is data from a separate biological replicate. (D) Average specific product formation rates $( \pm \mathrm{SD})$ in $E$. coli cell suspensions for the indicated time frames, determined from the data in A-C. Fold changes in specific formation rates are shown for days $1-7$ relative to days $0-1$. Figure S8A is the same data that appeared in Supplementary Figure 1 in LaSarre et al., 2017. 
Table S1. Strains, plasmids and primers used in this study.

\begin{tabular}{|c|c|c|}
\hline \multicolumn{3}{|c|}{ R. palustris strains; designation in paper } \\
\hline CGA009 & $\begin{array}{l}\text { Wild-type strain; spontaneous } \mathrm{Cm}^{\mathrm{R}} \text { derivative of } \\
\text { CGA001 }\end{array}$ & $\begin{array}{l}\text { (Larimer et al., } \\
\text { 2004) }\end{array}$ \\
\hline CGA4004 & CGA009 $\Delta$ hupS $\Delta r p a 2750$; Parent & $\begin{array}{l}\text { (LaSarre et al., } \\
\text { 2017) }\end{array}$ \\
\hline CGA4005 & CGA4004 nifA *; $\underline{\mathrm{Nx}}$ & $\begin{array}{l}\text { (LaSarre et al., } \\
\text { 2017) }\end{array}$ \\
\hline \multicolumn{3}{|l|}{ E. coli strains } \\
\hline MG1655 & $\begin{array}{l}\text { Wild-type K12 obtained from the Coli Genetic } \\
\text { Stock Center (\# 7740, MG1655(Seq)), WT }\end{array}$ & $\begin{array}{l}\text { (Blattner et al., } \\
\text { 1997) }\end{array}$ \\
\hline JW2004-1 & 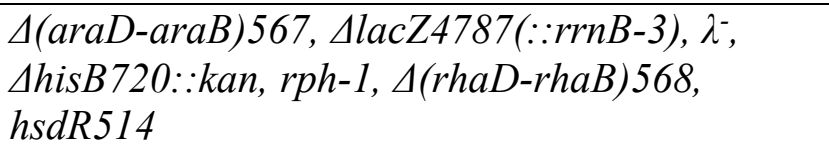 & (Baba et al., 2006) \\
\hline MG1655 $\Delta$ HisB & MG1655 $\Delta$ hisB720::Km & This study \\
\hline
\end{tabular}

2 
Table S2. Default parameter values used in the model unless stated otherwise

\begin{tabular}{|c|c|c|}
\hline Parameter & Value & Description (Units); Source \\
\hline$\mu_{\mathrm{EcMAX}}$ & 0.2800 & E. coli max growth rate $\left(\mathrm{h}^{-1}\right)$; Monoculture \\
\hline$\mu_{\mathrm{RpMAX}}$ & 0.0772 & R. palustris max growth rate $\left(\mathrm{h}^{-1}\right)$; Monoculture \\
\hline $\mathrm{G}$ & 25 & Glucose $(\mathrm{mM})$ \\
\hline $\mathrm{A}$ & 0.00005 & $\mathrm{NH}_{4}^{+}(\mathrm{mM})$; from initial $\left(\mathrm{NH}_{4}\right)_{6} \mathrm{Mo}_{7} \mathrm{O}_{24} \cdot 4 \mathrm{H}_{2} \mathrm{O}$ concentration \\
\hline $\mathrm{C}$ & 0 & $\begin{array}{l}\text { Consumable organic acids (those that } R . \text { palustris was observed to consur } \\
\text { succinate; } \mathrm{mM} \text { ) }\end{array}$ \\
\hline $\mathrm{N}$ & 70 & $\mathrm{~N}_{2}$ (assumed to be fully dissolved; $\mathrm{mM}$ ) \\
\hline $\mathrm{f}$ & 0 & Formate $(\mathrm{mM})$ \\
\hline $\mathrm{e}$ & 0 & Ethanol (mM) \\
\hline $\mathrm{CO} 2$ & 0 & Carbon dioxide $(\mathrm{mM})$ \\
\hline $\mathrm{K}_{\mathrm{G}}$ & 0.02 & E. coli affinity (Michaelis-Menten constant $(\mathrm{Km}))$ for glucose $(\mathrm{mM}) ;(\mathrm{Bu}$ \\
\hline $\mathrm{K}_{\mathrm{C}}$ & 0.01 & R. palustris affinity $(\mathrm{Km})$ for consumable organic acids $(\mathrm{mM})$; Assumed \\
\hline $\mathrm{K}_{\mathrm{A}}$ & 0.01 & E. coli affinity for $\mathrm{NH}_{4}^{+}(\mathrm{mM}) ;($ Khademi et al., 2004) \\
\hline $\mathrm{K}_{\mathrm{N}}$ & 6 & $\begin{array}{l}\text { R. palustris affinity }(\mathrm{Km}) \text { for } \mathrm{N}_{2}(\mathrm{mM}) \text {; determined by fitting a Michaelis } \\
\text { of coculture growth rates versus } \mathrm{N}_{2} \text { concentration (Figure } \mathrm{S} 5 \text { ). }\end{array}$ \\
\hline Ec & $0.4 \times 10^{7}$ & E. coli cell density (cells / ml) \\
\hline $\mathrm{Rp}$ & $3.6 \times 10^{7}$ & R. palustris cell density (cells / $\mathrm{ml}$ ) \\
\hline$b_{\mathrm{Ec}}$ & $10^{43}$ & Resistance of $E$. coli to low $\mathrm{pH}(\mathrm{mM})^{\mathrm{a}}$ \\
\hline $\mathrm{b}_{\mathrm{Rp}}$ & $10^{32}$ & Resistance of $R$. palustris to low $\mathrm{pH}(\mathrm{mM})^{\mathrm{a}}$ \\
\hline $\mathrm{Y}_{\mathrm{G}}$ & $8 \times 10^{7}$ & $\begin{array}{l}\text { Glucose-limited } E \text {. coli growth yield (cells / } \mu \text { mol glucose); Determined b } \\
\text { by the concentration of glucose consumed at early stationary phase in gluc } \\
\text { monocultures }\end{array}$ \\
\hline $\mathrm{Y}_{\mathrm{A}}$ & $1 \times 10^{9}$ & $\begin{array}{l}\mathrm{NH}_{4}{ }^{+} \text {-limited } E \text {. coli growth yield (cells / } \mu \mathrm{mol} \mathrm{NH}_{4}{ }^{+} \text {); Determined by } \mathrm{div} \\
\text { the concentration of } \mathrm{NH}_{4}{ }^{+} \text {used at early stationary phase in } \mathrm{NH}_{4}{ }^{+} \text {-limited } E\end{array}$ \\
\hline $\mathrm{Y}_{\mathrm{C}}$ & $2.5 \times 10^{8}$ & $\begin{array}{l}\text { Organic acid-limited } R \text {. palustris growth yield (cells / } \mu \text { mol organic acid) } \\
\text { dividing the CFU } / \mathrm{ml} \text { by the concentration of acetate used at early stationar } \\
\text { limited } R \text {. palustris monocultures }\end{array}$ \\
\hline $\mathrm{Y}_{\mathrm{N}}$ & $5 \times 10^{8}$ & $\begin{array}{l}\mathrm{N}_{2} \text {-limited } R \text {. palustris growth yield cells / } \mu \text { mol } \mathrm{N}_{2} ; \text { Determined by divin } \\
\text { concentration of } \mathrm{N}_{2} \text { used at early stationary phase in } \mathrm{N}_{2} \text {-limited } R \text {. palustri. }\end{array}$ \\
\hline $\mathrm{R}_{\mathrm{C}}$ & $1.9 \times 10^{-8}$ & Fraction of glucose converted to organic acids $(\mu \mathrm{mol} \text { glucose } / \text { cell })^{\mathrm{a}}$ \\
\hline $\mathrm{R}_{\mathrm{f}}$ & $8 \times 10^{-9}$ & Fraction of glucose converted to formate $(\mu \mathrm{mol} \text { glucose / cell })^{\mathrm{a}}$ \\
\hline $\mathrm{R}_{\mathrm{e}}$ & $4.5 \times 10^{-9}$ & Fraction of glucose converted to ethanol $(\mu \mathrm{mol} \text { glucose } / \text { cell })^{\mathrm{a}}$ \\
\hline $\mathrm{R}_{\mathrm{CO} 2}$ & $5 \times 10^{-10}$ & Fraction of glucose converted to $\mathrm{CO}_{2}(\mu \mathrm{mol} \text { glucose / cell })^{\mathrm{a}}$ \\
\hline $\mathrm{R}_{\mathrm{HRp}}$ & $2 \times 10^{-9}$ & R. palustris $\mathrm{H}_{2}$ production $\left(\mu \mathrm{mol} \mathrm{H}_{2} / R \text {. palustris cell }\right)^{\mathrm{a}}$ \\
\hline $\mathrm{R}_{\mathrm{HEc}}$ & $5 \times 10^{-9}$ & E. coli $\mathrm{H}_{2}$ production $\left(\mu \mathrm{mol} \mathrm{H} \mathrm{H}_{2} / \text { E. coli cell }\right)^{\mathrm{a}}$ \\
\hline $\mathrm{R}_{\mathrm{A}}$ & $0.15 \times 10^{-9}$ & R. palustris $\mathrm{NH}_{4}{ }^{+}$production $\left(\mu \mathrm{mol} \mathrm{NH}{ }^{+} / \text {cell }\right)^{\mathrm{a}}$ \\
\hline $\mathrm{r}_{\mathrm{C}}$ & $300 \times 10^{-11}$ & $\begin{array}{l}\text { E. coli specific growth-independent rate of glucose conversion to consum } \\
(\mu \mathrm{mol} \text { glucose } / \text { cell } / \mathrm{h})^{\mathrm{a}}\end{array}$ \\
\hline $\mathrm{r}_{\mathrm{f}}$ & $47 \times 10^{-11}$ & $\begin{array}{l}\text { E. coli specific growth-independent rate of glucose conversion to formate } \\
\text { h) }\end{array}$ \\
\hline $\mathrm{r}_{\mathrm{e}}$ & $15 \times 10^{-11}$ & $\begin{array}{l}\text { E. coli specific growth-independent rate of glucose conversion to ethanol } \\
\text { h) }\end{array}$ \\
\hline
\end{tabular}




\begin{tabular}{|c|c|c|}
\hline $\mathrm{r}_{\mathrm{CO} 2}$ & $2 \times 10^{-11}$ & E. coli specific growth-independent rate of glucose conversion to $\mathrm{CO}_{2}(\mu \mathrm{r}$ \\
\hline $\mathrm{r}_{\mathrm{H}}$ & $2 \times 10^{-11}$ & E. coli specific growth-independent rate of $\mathrm{H}_{2}$ production $\left(\mu \mathrm{mol} \mathrm{H}_{2} /\right.$ cell \\
\hline $\mathrm{r}_{\mathrm{C} \_ \text {mono }}$ & $1.2 \times 10^{-11}$ & $\begin{array}{l}\text { E. coli specific growth-independent rate of glucose conversion to consum } \\
\text { when consumable organic acids accumulate }(\mu \mathrm{mol} \text { glucose } / \text { cell / h })^{\mathrm{b}}\end{array}$ \\
\hline $\mathrm{r}_{\mathrm{f} \text { mono }}$ & $0.83 \times 10^{-11}$ & $\begin{array}{l}\text { E. coli specific growth-independent rate of glucose conversion to formate } \\
\text { organic acids accumulate }(\mu \mathrm{mol} \text { glucose / cell / h })^{\mathrm{b}}\end{array}$ \\
\hline $\mathrm{r}_{\mathrm{e}-\mathrm{mono}}$ & $0.5 \times 10^{-11}$ & $\begin{array}{l}\text { E. coli specific growth-independent rate of glucose conversion to ethanol } \\
\text { organic acids accumulate }(\mu \mathrm{mol} \text { glucose / cell / h })^{\mathrm{b}}\end{array}$ \\
\hline $\mathrm{r}_{\mathrm{co} 2 \_\mathrm{mono}}$ & $1.3 \times 10^{-11}$ & $\begin{array}{l}\text { E. coli specific growth-independent rate of glucose conversion to } \mathrm{CO}_{2} \mathrm{wh} \\
\text { acids accumulate }(\mu \mathrm{mol} \text { glucose / cell / h })^{\mathrm{b}}\end{array}$ \\
\hline $\mathrm{r}_{\mathrm{H} \_ \text {mono }}$ & $0.83 \times 10^{-11}$ & $\begin{array}{l}\text { E. coli specific growth-independent rate of glucose conversion to } \mathrm{H}_{2} \text { whe } \\
\text { acids accumulate }(\mu \mathrm{mol} \text { glucose / cell / h })^{\mathrm{b}}\end{array}$ \\
\hline $\mathrm{r}_{\mathrm{Hp}}$ & $27 \times 10^{-11}$ & R. palustris specific growth-independent rate of $\mathrm{H}_{2}$ production $\left(\mu \mathrm{mol} \mathrm{H} \mathrm{H}_{2}\right)$ \\
\hline
\end{tabular}

${ }^{a}$ Values were manually varied until simulated trends resembled empirical trends observed in both monoculture and coculture (i.e., growth inhibition at a given cumulative concentration of formate and other organic acids). Growth-independent fermentation rates were increased to account for R. palustris's pull on E. coli metabolism by consuming organic acids. ${ }^{\mathrm{b}}$ Determined from rates of product formation from glucose measured between days 1 and 7 of $E$. coli cell suspensions, wherein growth was prevented by omitting all nitrogen sources. Representative plots of fermentation product accumulation under these conditions is available in Figure S8.

\section{Supplementary References}

Baba, T., Ara, T., Hasegawa, M., Takai, Y., Okumura, Y., Baba, M., et al. (2006) Construction of Escherichia coli K-12 in-frame, single-gene knockout mutants: the Keio collection. Mol. Syst. Biol. 2: 2006.0008.

Blattner, F., Plunkett G, I., Bloch, C., Perna, N., Burland, V., Riley, M., et al. (1997) The complete genome sequence of Escherichia coli K-12. Science. 2771613: 1453-1462.

Buhr, A., Daniels, G.A., and Erni, B. (1992) The glucose transporter of Escherichia coli: Mutants with impaired translocation activity that retain phosphorylation activity. J. Biol. Chem. 267: 3847-3851.

Khademi, S., O’Connell 3rd, J., Remis, J., Robles-Colmenares, Y., Miercke, L.J., and Stroud, R.M. (2004) Mechanism of ammonia transport by Amt/MEP/Rh: structure of AmtB at 1.35 A. Science. 305: 1587-1594.

Larimer, F.W., Chain, P., Hauser, L., Lamerdin, J., Malfatti, S., Do, L., et al. (2004) Complete genome sequence of the metabolically versatile photosynthetic bacterium Rhodopseudomonas palustris. Nat. Biotechnol. 22: 55-61.

LaSarre, B., McCully, A.L., Lennon, J.T., and McKinlay, J.B. (2017) Microbial mutualism dynamics governed by dose-dependent toxicity of cross-fed nutrients. ISME J 11: 337-348.

McKinlay, J.B., Oda, Y., Ruhl, M., Posto, A.L., Sauer, U., and Harwood, C.S. (2014) Nongrowing Rhodopseudomonas palustris increases the hydrogen gas yield from acetate by shifting from the glyoxylate shunt to the tricarboxylic acid cycle. J. Biol. Chem. 4: 19601970. 